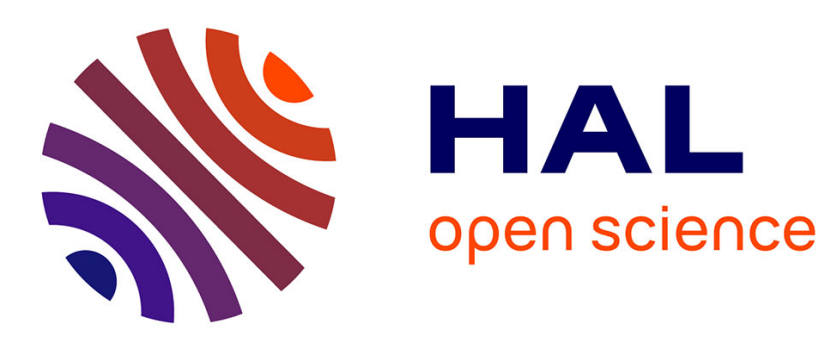

\title{
Autoimmunity, neuroinflammation, pathogen load: A decisive crosstalk in neuropsychiatric SLE
}

Hélène Jeltsch-David, Sylviane Muller

\section{To cite this version:}

Hélène Jeltsch-David, Sylviane Muller. Autoimmunity, neuroinflammation, pathogen load: A decisive crosstalk in neuropsychiatric SLE. Journal of Autoimmunity, 2016, 74, pp.13-26. 10.1016/j.jaut.2016.04.005 . hal-02347302

\section{HAL Id: hal-02347302 https://hal.science/hal-02347302}

Submitted on 26 Nov 2019

HAL is a multi-disciplinary open access archive for the deposit and dissemination of scientific research documents, whether they are published or not. The documents may come from teaching and research institutions in France or abroad, or from public or private research centers.
L'archive ouverte pluridisciplinaire HAL, est destinée au dépôt et à la diffusion de documents scientifiques de niveau recherche, publiés ou non, émanant des établissements d'enseignement et de recherche français ou étrangers, des laboratoires publics ou privés. 
Review article

\title{
Autoimmunity, neuroinflammation, pathogen load: A decisive crosstalk in neuropsychiatric SLE
}

\author{
Hélène Jeltsch-David ${ }^{\mathrm{a}}$, Sylviane Muller ${ }^{\mathrm{a}, \mathrm{b}, \text { * }^{*}}$ \\ ${ }^{a}$ Centre National de la Recherche Scientifique (CNRS), Immunopathologie et Chimie Thérapeutique/Laboratory of excellence Medalis, Institut de Biologie \\ Moléculaire et Cellulaire, 15 rue René Descartes, 67000 Strasbourg, France \\ ${ }^{\mathrm{b}}$ University of Strasbourg Institute for Advanced Study, 67000 Strasbourg, France
}

\section{A R T I C L E I N F O}

\section{Article history:}

Received 10 April 2016

Received in revised form 21 April 2016

Accepted 24 April 2016

Available online 29 April 2016

\section{Keywords:}

Autoantibodies

Brain

Infection

Lupus

Neuroimmunology

Therapy

\begin{abstract}
A B S T R A C T
Depicting the cellular and molecular bases of the continuous dialogue existing between the peripheral immune and the central nervous systems, as in neurolupus, is fundamental to improve, and better apprehend the role played by immune cells and mediators in the initiation and progression of neurological and psychiatric diseases, which nowadays remain a major public health issue. The relative frequency of neurological symptoms occurring in systemic autoimmunity is particularly worrying as, for example, two-thirds of patients with lupus will eventually experience the disabling effects of neuropsychiatric lupus. Neurolupus is a particularly severe form of lupus with wide-ranging symptoms, which contribute to increased mortality and morbidity in patients. In this context, infections, which suddenly trigger exacerbations of the otherwise mild lupus disease, may drive the progression of neuroinflammation and neurodegeneration via different mechanisms involving a network of effector molecules and cells. The complex interaction of neuroimmunology and neuroinfectiology represents a genuine challenge for basic scientists and clinicians to understand the mechanisms that are implicated, and identify possible biomarkers of severity that might predict the development of this devastating form of lupus. The ultimate goal is to design appropriate, personalised therapeutic strategies to improve the outcome of the disease.
\end{abstract}

\section{Contents}

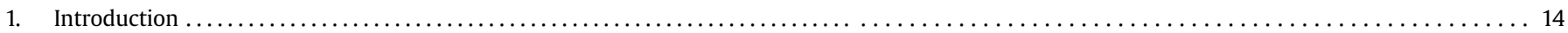

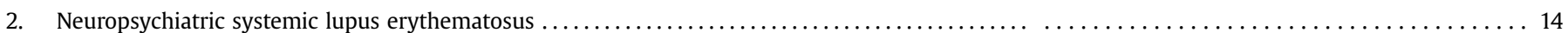

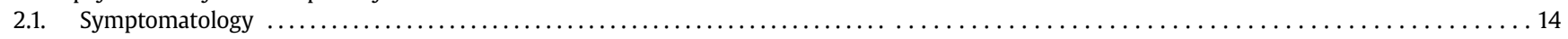

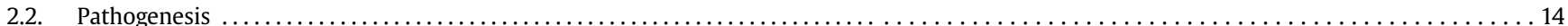

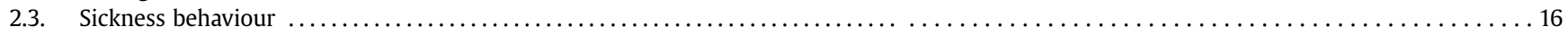

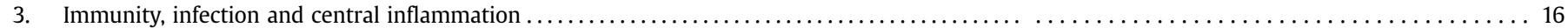

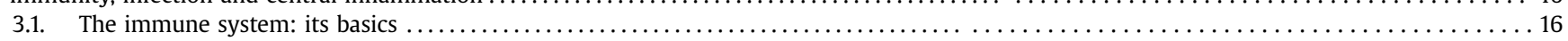

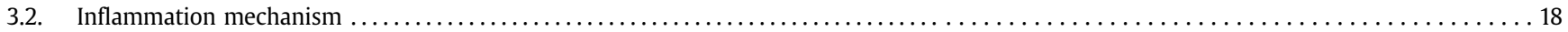

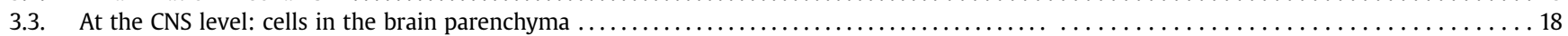

Abbreviations: Abs, antibodies; AID, autoimmune disease; BBB, blood-brain barrier; CMA, chaperone-mediated autophagy; CNS, central nervous system; CSF, cerebro-

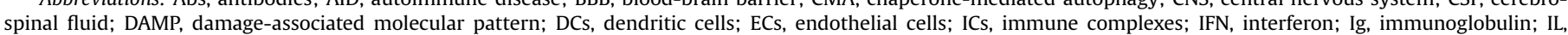

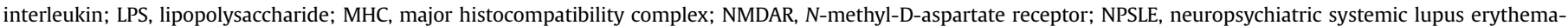

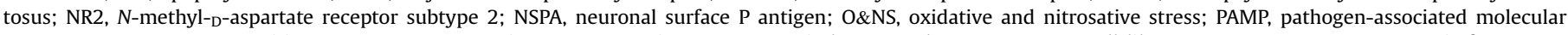

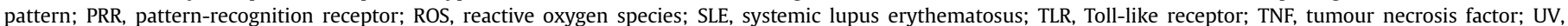
ultraviolet.

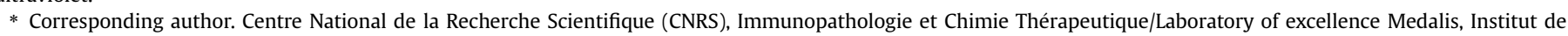
Biologie Moléculaire et Cellulaire, 15 rue René Descartes, 67000 Strasbourg, France.

E-mail addresses: H.David@ibmc-cnrs.unistra.fr (H. Jeltsch-David), S.Muller@ibmc-cnrs.unistra.fr (S. Muller). 


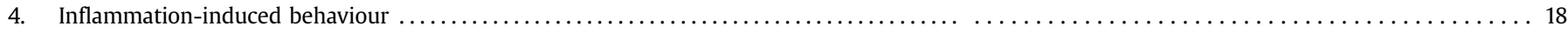

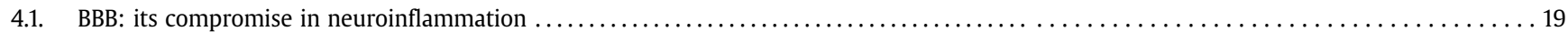

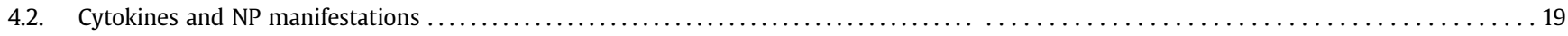

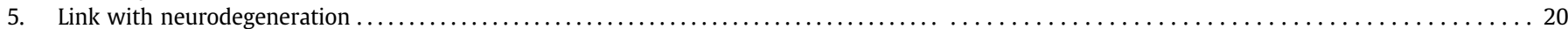

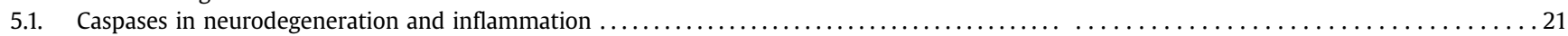

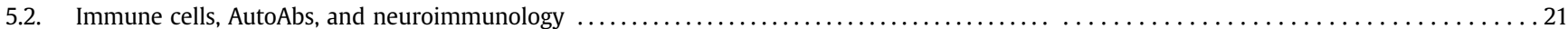

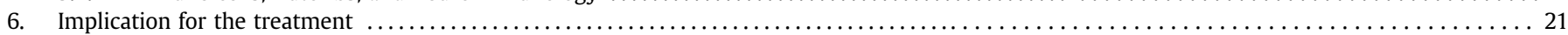

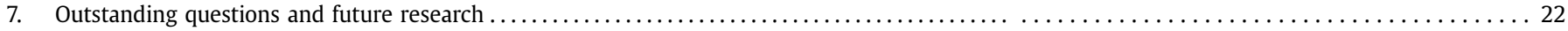

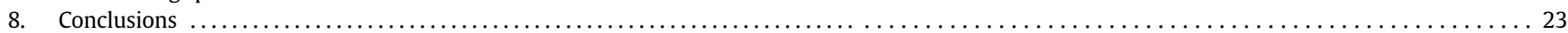

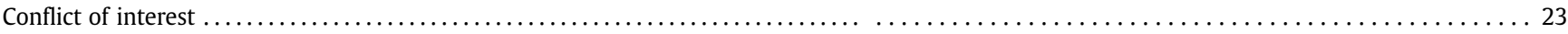

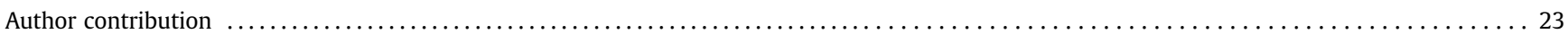

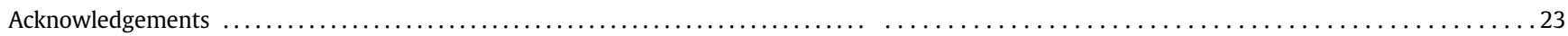

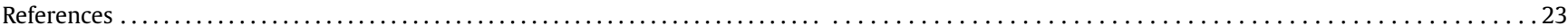

\section{Introduction}

It has long been established that neuropsychiatric (NP) diseases can be elicited by infectious pathogens, diet, or environmental components [1]. Despite intensive investigation, however, the aetiology of most NP diseases as well as autoimmune diseases (AIDs) remains elusive. The interplay of hormonal, immunological, and environmental factors associated to a genetically-predisposed ground appears to be central but nowadays, it is not known how these intrinsic and extrinsic factors associate to trigger the disease, what are the host elements that are involved to orientate the form of the disease in a particular individual, and what regulates acute exacerbation and remission phases in certain AIDs. Autoimmunity may profoundly impact the continuous crosstalk held between the central nervous system (CNS) and the immune system contributing to the emergence of symptoms such as depression, mood and anxiety disorders, or psychosis [2-4]. Some of these symptoms have been reported to occur in neuropsychiatric systemic lupus erythematosus (NPSLE).

In this complex picture, infections have been described as decisive factors that not only trigger but also sustain and exacerbate AIDs. Epidemiological studies show that the occurrence of SLE differs according to countries, to areas of the same country and between social groups. These differences suggest that besides genetic susceptibility and intrinsic factors, environmental elements, notably the infectious environment and the level of hygiene in different world areas, are central in the development of this syndrome [5]. The composition of gut microbiota [6], which may change as a function of diet modification or following medication, can also modulate and aggravate the course of SLE.

After summarizing the current consensus views of NPSLE pathogenesis, this review will focus on the possible ways infectious agents may influence autoimmunity, the mechanisms of neuroinflammation and inflammation-induced behaviour, what they imply in terms of blood-brain barrier (BBB) permeability, brain cytokines and how, nowadays, we progress in our understanding of neurodegeneration in NPSLE. A better understanding this "ménage à trois" (brain, immune system and infectious agents) in a disease where there is still no specific treatment, is pivotal in our quest to design novel therapeutic options based on personalised approaches.

\section{Neuropsychiatric systemic lupus erythematosus}

\subsection{Symptomatology}

SLE is a prototypic relapsing-remitting AID identified by elevated titres of inflammatory mediators, hyper-activation of peripheral B and T lymphocytes, production of potentially pathogenic autoantibodies (autoAbs), clearance failure and tissue deposition of immune complexes (ICs). These events precede inflammatory conditions, which may cause end-organ damage [7]. SLE prevalence fluctuates from 40 to 100 cases per 100,000 individuals, and even 40 to 200 among blacks in the US [8,9]. The influence of hormones is central as $90 \%$ of patients are female and the vast majority of cases occur during childbearing age. Linkage between genetic and environmental factors (e.g. infections, pollutants, UV radiation, stress) might underpin disease bursts and justify the "waxing and waning" symptoms [10,11]. Although skin, arthritis and renal lesions are the most common manifestations, neurological and NP symptoms occur frequently [12]. When severe, they substantially contribute to the morbidity and mortality rates of patients [13].

NPSLE is a yet poorly understood disease that encompasses some twenty central and peripheral symptoms (Table 1). CNS symptoms largely predominate (93\%) and may be diffuse or focal [14]. The majority of NP manifestations appears early in the course of SLE, most of them being not correlated with flare or severity of the disease. NPSLE is essentially clinically-defined by physical examination, brain imaging, and serological, psychiatric and neuropsychological tests. However, despite improved imaging, diagnosing NPSLE still remains a challenge [15-18]. The prevalence of NP events ranges from $14 \%$ to $75 \%$ [19,20], reflecting important differences in patient selection resulting from the absence of consensus for diagnosing NPSLE. The genetics of NPSLE has rarely been addressed. Of note, the gene TREX1 involved in apoptosis, oxidative stress and several cerebral diseases has been linked to NPSLE [21]. Larger genome-wide association studies of lupus patients are therefore eagerly awaited.

\subsection{Pathogenesis}

The pathogenesis of NPSLE is particularly complex. The presence of a chronic inflammatory state is commonly reported but no single pathogenic dysfunction accounts for all NP symptoms, which result from several pathogenic pathways including vascular and neuroinflammatory circuits (Fig. 1) [14,22,23].

Much data demonstrate that some NP symptoms are caused by antiphospholipid Abs, which bind to clotting factors and endothelial cells (ECs), inducing a pro-coagulant state. This mostly results in focal manifestations that can be associated with structural brain abnormalities at autopsy [24]. Both in murine models of lupus [25-28] and in patients [29,30], diffuse manifestations were found to result rather from inflammatory processes and toxicity mediated by Abs binding neuronal cell surface receptors, such as neuronal surface $\mathrm{P}$ antigen (NSPA) and $N$-methyl-D-aspartate receptor 
Table 1

Neuropsychiatric syndromes described in lupus (ACR ${ }^{\mathrm{a}}$ classification [145]) (adapted from Refs. [14,146]).

\begin{tabular}{|c|c|}
\hline Central nervous system & \\
\hline $\begin{array}{l}\text { Diffuse psychiatric/neuropsychological syndromes } \\
\text { Mood and anxiety disorders }{ }^{\mathrm{b}} \\
\text { Cognitive dysfunction }^{\mathrm{b}} \\
\text { Headaches }^{\mathrm{b}} \\
\text { Psychosis }^{\mathrm{c}} \\
\text { Depression } \\
\text { Acute confusional state }\end{array}$ & $\begin{array}{l}\text { Focal neurological syndromes } \\
\text { Stroke }^{\mathrm{b}} \\
\text { Seizures }^{\mathrm{c}} \\
\text { Aseptic meningitis } \\
\text { Movement disorder } \\
\text { Myelopathy } \\
\text { Demyelinating syndrome }\end{array}$ \\
\hline \multicolumn{2}{|l|}{ Peripheral nervous system } \\
\hline $\begin{array}{l}\text { Autonomic neuropathy } \\
\text { Cranial neuropathy } \\
\text { Polyneuropathy } \\
\text { Mononeuropathy (single/multiplex) } \\
\text { Myasthenia gravis } \\
\text { Plexopathy } \\
\text { Guillain-Barré syndrome }\end{array}$ & \\
\hline
\end{tabular}

(NMDAR). The occurrence of autoAbs and proinflammatory cytokines in the cerebrospinal fluid (CSF), a liquid secreted within the choroid plexus and diffusing into the cerebroventricular compartments, could either result from leakages in the BBB (passive transfer) or from intrathecal production [31]. Breach of the BBB is critical for the access of Abs directed against NMDAR subunit 2 (anti-NR2, also known as anti-GluN2) to brain neurons [26,32,33]. The BBB can be permeabilised by SLE-linked factors (e.g. cytokines,

\begin{tabular}{|c|c|c|c|}
\hline $\begin{array}{c}\text { Genetic factors } \\
\text { (IRF5 and TRPC6 variants, mutation } \\
\text { in TREX1, HLA-DRB1*04 genotype, } \\
\text { STAT4 rs10181656) }\end{array}$ & \multicolumn{2}{|c|}{$\begin{array}{l}\text { Neuroendocrine factors } \\
\text { (HPA axis, sex hormones, } \\
\text { glucocorticoids } \\
\text { and neuropeptides synthesis) }\end{array}$} & $\begin{array}{l}\text { Environmental factors } \\
\text { Infections, pollutants, stress, } \\
\text { smoking, UV light, diet habits) }\end{array}$ \\
\hline \multicolumn{2}{|c|}{$\begin{array}{c}\text { Inflammatory mechanisms: BBB dysfunction } \\
\text { Cytokines/chemokines (IL-1 } \beta, \text { IL-6, IL-10, TNF } \alpha \text {, IFN } \gamma \text { ) } \\
\text { Autoantibodies (anti-NR2, anti-NSPA) }\end{array}$} & \multicolumn{2}{|c|}{$\begin{array}{c}\text { Vascular mechanisms: occlusion, haemorrhage } \\
\text { antiphospholipid antibodies (lupus anticoagulant, } \\
\text { anticardiolipin, anti- } \beta 2 \mathrm{GP} 1 \text { ) } \\
\text { Immune complexes }\end{array}$} \\
\hline \multicolumn{2}{|c|}{$\begin{array}{c}\text { Pathological processes } \\
\text { Immune cells recruitment } \\
\text { Activation of the HPA axis and the vagus nerve } \\
\text { Implication of steroid hormones } \\
\text { Complement and microglial cells activation } \\
\text { Direct central nervous tissue injury (by excitatory amino } \\
\text { acid toxicity, oxidative stress, PAI-1 or MMP) } \\
\text { Neuronal cell death by apoptosis }\end{array}$} & $\begin{array}{r}\text { Immune activ } \\
\text { Altered syr }\end{array}$ & $\begin{array}{l}\text { logical processes } \\
\text { rivascular lymphocytic infiltration, } \\
\text { ry mediators production, } \\
\text { ial cells proliferation) } \\
\text { crovasculopathy } \\
\text { rebral ischemia } \\
\text { rebral atrophy } \\
\text { ansmission/ neurodegeneration }\end{array}$ \\
\hline \multicolumn{4}{|c|}{ Neuropsychiatric manifestations of lupus } \\
\hline \multicolumn{2}{|c|}{$\begin{array}{l}\text { Mostly early functional damage } \\
\text { Diffuse manifestations (e.g. cognitive dysfunction, } \\
\text { mood and anxiety disorders, depression) } \\
\text { without structural pathology }\end{array}$} & $\begin{array}{r}\text { Focal } n \\
\text { associat } \\
\text { But also diffus }\end{array}$ & $\begin{array}{l}\text { structural damage } \\
\text { ations (e.g. seizures, stroke, } \\
\text { rovascular disease) } \\
\text { uctural pathology at autopsy } \\
\text { tations (without structural pathology) }\end{array}$ \\
\hline
\end{tabular}

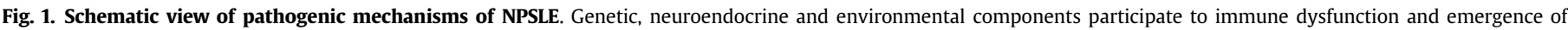

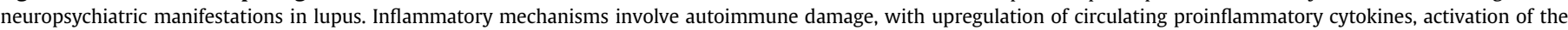

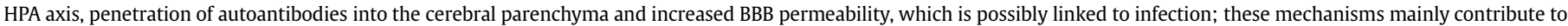

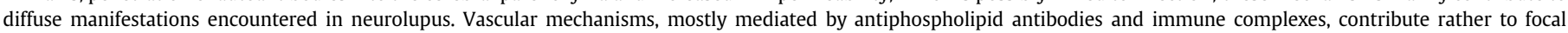

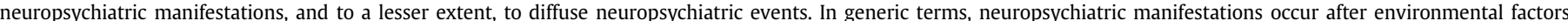

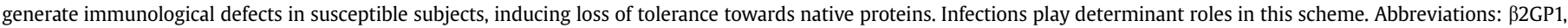

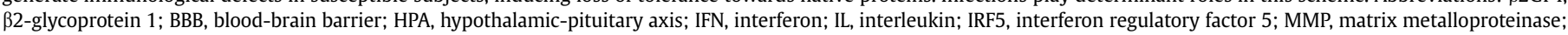

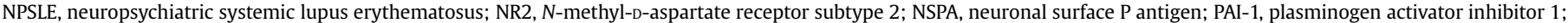

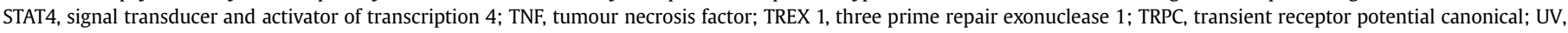
ultraviolet. 
autoAbs) and non-SLE factors (e.g. LPS, viral proteins, UV, stress, hormones, smoking, certain addictive drugs) (Table 2) [34]. In NPSLE, leakage in the BBB might be induced by the binding of glutamate to NMDARs localised on brain ECs. NSPA participates to NMDAR function, glutamatergic transmission and hippocampal memory by moderating the detrimental action of anti-ribosomal $\mathrm{P}$ protein Abs. Diffuse NPSLE symptoms may arise after these autoAbs gain access to cerebral areas co-expressing both NMDAR and NSPA. Importantly, these two SLE-related autoAbs recognizing NSPA influence glutamatergic transmission, albeit via distinctive processes [35].

Increased intrathecal production of several cytokines (Fig. 1) by neuronal and glial cells, presumably following intrathecal presence of autoAbs, is also linked to NP manifestations in lupus [36-38]. As suggested from in vitro studies, cytokines are produced after binding of ICs to Fc $\beta$ RII on plasmacytoid dendritic cells (DCs; which are major antigen-presenting cells of the immune system) and stimulation of TLR7. This mechanism is substantiated by the presence, in the CSF of NPSLE patients, of degraded neuronal and glial material (potential antigens source), and increased matrix metalloproteinase-9 levels [39], which augment BBB permeability, thus providing intrathecal access to circulating autoAbs $[22,40]$. It is worth mentioning that high levels of oxidative and nitrosative stress (O\&NS) are significantly associated to neurodegeneration and might be an important component of NPSLE [41]. Whether neurological dysfunction progresses independently, results from systemic disorder, or both, remains unclear. In fact, CNS dysfunction and NP manifestations could be part of existing disease or they could be consecutive to treatment, infection, and metabolic dysfunctions.

\subsection{Sickness behaviour}

Depression, fatigue, anhedonia and defects in cognition are frequently noted in clinical conditions where inflammation is always reported, which could then be considered as a pivotal contributor to the expression of such symptoms [42,43]. In rodents, alteration in cognition, emotionality and sleep-wake cycle is detected after peripheral immune activation [44]. These modifications coexisting with activation of the peripheral immune system are known as "sickness behaviour" [45,46], which is welldocumented in SLE and in spontaneous murine models, notably in MRL/lpr lupus-prone mice. As compared to $\mathrm{MRL}^{+/+}$mice counterparts, MRL/lpr mice display deficient cognitive performances in spontaneous alternation (Fig. 2; Jeltsch-David and Muller, unpublished observations) and water maze tasks, suggestive of hippocampal dysfunction and consequences on the neural processing of learning and memory $[47,48]$. It is worth noting that SLE patients displaying cognitive difficulties may also present structural hippocampal anomalies [46,49].

\section{Immunity, infection and central inflammation}

\subsection{The immune system: its basics}

The immune system includes the innate and the adaptive systems, and is composed by cells adjusted to protect the organism against foreign agents, while being nonreactive towards self [50]. The body responds to pathogenic exogenous and endogenous signals with comparable reactions via sentinel cells (e.g. monocytes, macrophages, DCs, microglia), which initiate an inflammatory response followed by a "mirrored" immune reaction within the CNS (neuroinflammation), possibly resulting in behavioural symptoms. Pathogenic agents exhibit pathogen-associated molecular patterns (PAMPs) that activate pattern-recognition receptors (PRRs). The latter recognise PAMPs as non-self-molecules and damageassociated molecular patterns (DAMPs) as self-molecules. Both give rise to innate response, one to eradicate invading elements and the other to eliminate injured tissue. Among the most widely studied PRRs are TLRs, which, for some, recognise extracellular pathogens (primarily bacteria) and for others, present within endosomes and lysosomes, interact with intracellular pathogens (Table 3). The activation of TLRs promotes inflammatory responses by generating intracellular signalling cascades via two main pathways, namely myeloid differentiation primary response 88 (MyD88) and Tir-domain-containing adaptor inducing interferon- $\beta$ (TRIF) pathways. Almost all TLRs combine MyD88 inaugurating a series of events to finally initiate $\mathrm{NF}_{\mathrm{K}} \mathrm{B}$, whose translocation directly stimulates gene transcription of TNF $\alpha$, IL-1 $\beta$ and IFN $\gamma$. Only TLR3 strictly associates with TRIF signalling to induce IFN $\alpha$ and IFN $\beta$. TRIF pathway seems to mainly play a role against viral infections, and Myd88 against bacterial ones. Concerning Nod-like receptors, they act similarly as TLRs by initiating inflammatory reactions after recognition of bacteria's peptidoglycans.

Table 2

Examples of factors modulating the BBB's ${ }^{\mathrm{a}}$ permeability (data adapted from Ref. [34]).

\begin{tabular}{|c|c|c|}
\hline Conditions & Substances & Action \\
\hline \multirow[t]{5}{*}{ Infections } & LPS & ECs activation \\
\hline & & P-glycoprotein regulation \\
\hline & & Cytokines secretion \\
\hline & Viral proteins (e.g. HIV) & Tight junction dysfunction \\
\hline & & Perivascular macrophages and microglia activation \\
\hline \multirow[t]{3}{*}{ Inflammation } & Cytokines (e.g. TNF $\alpha$, IL-1 $\beta$, IL- & ECs activation \\
\hline & 6 , Type 1 IFN) & Tight junction dysfunction \\
\hline & $\begin{array}{l}\text { Circulating Abs (e.g. anti-NR2 } \\
\text { Abs, } \\
\text { anti-P autoAbs) }\end{array}$ & $\begin{array}{l}\text { Recognition of neuronal cell surface antigens, and enhancement of glutamatergic transmission through two different } \\
\text { mechanisms (when } \mathrm{Mg}^{2+} \text { is removed and in the presence of } \mathrm{Mg}^{2+} \text {, respectively); the mechanism mediated by NSPA } \\
\text { involves NMDAR activation }\end{array}$ \\
\hline \multirow[t]{2}{*}{ Stress, stroke } & Glutamate & 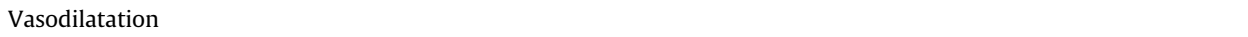 \\
\hline & & ECs activation \\
\hline \multirow{2}{*}{$\begin{array}{l}\text { Hormonal } \\
\text { dysfunctions }\end{array}$} & Estrogens (e.g. $17 \beta$-œstradiol) & Inhibition of MMP2 and MMP9 \\
\hline & $\begin{array}{l}\text { Glucocorticoids (e.g. } \\
\text { dexamethasone) }\end{array}$ & VEGF and angiopoietin regulation \\
\hline \multirow{3}{*}{$\begin{array}{l}\text { Addictive } \\
\text { agents }\end{array}$} & Tobacco (e.g. nicotine) & Tight junction modulation \\
\hline & Coffee (e.g. caffeine) & Action on junctional proteins by neurotoxins and other agents \\
\hline & Alcohol (e.g. ethanol) & Choroid plexus dysfunction \\
\hline
\end{tabular}

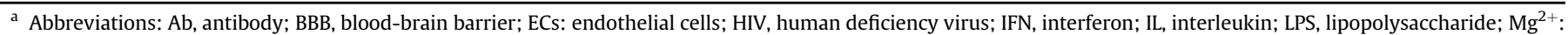

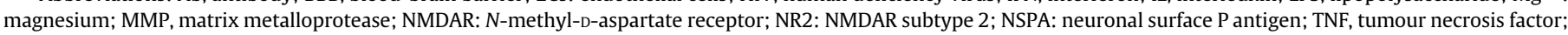
VEGF, vascular endothelial growth factor. 
(a)

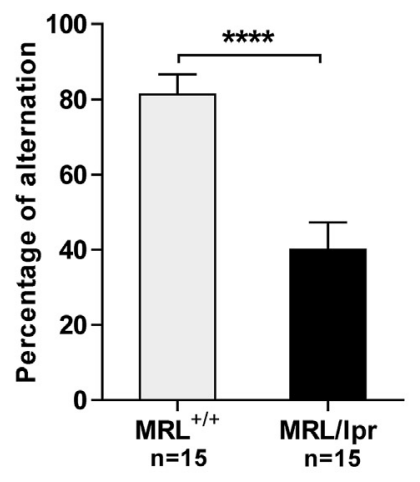

(c)

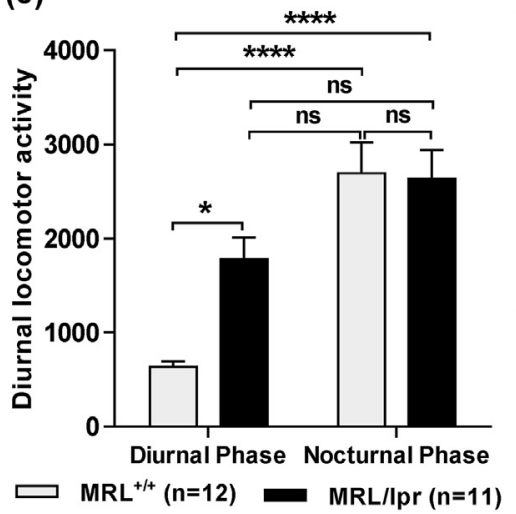

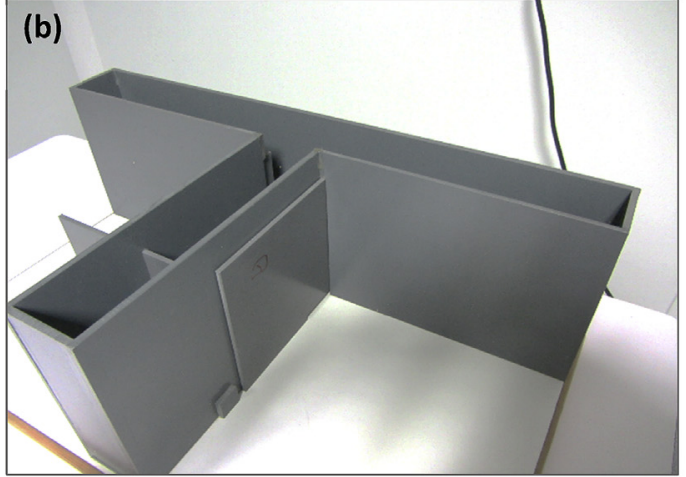

(d)

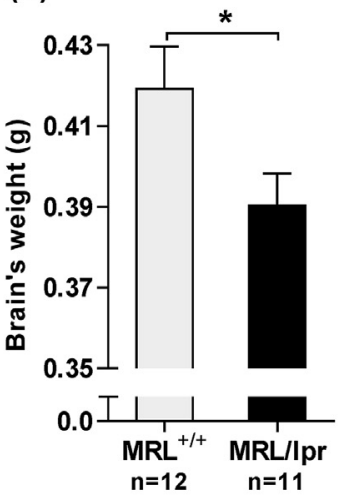

(e)

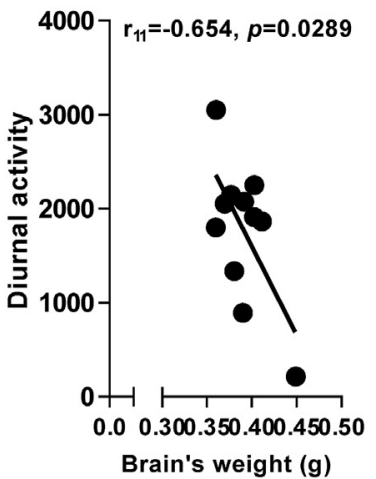

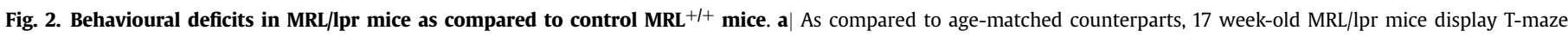

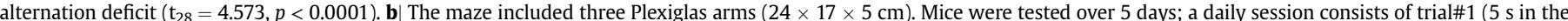

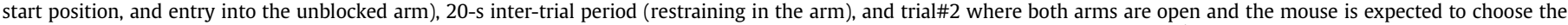

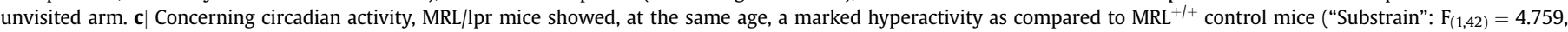

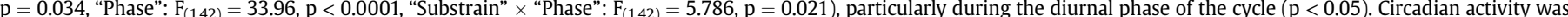

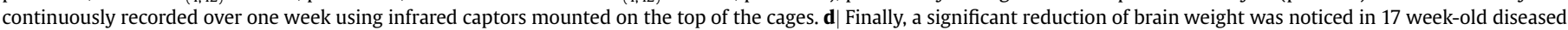

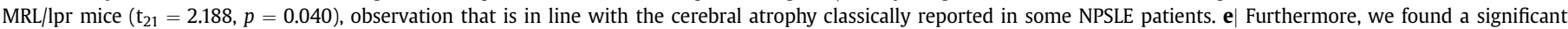

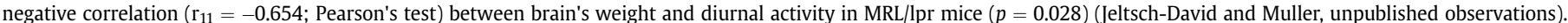

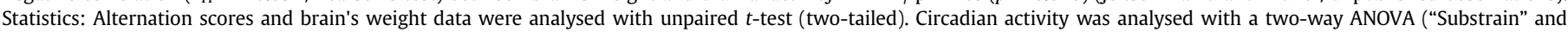

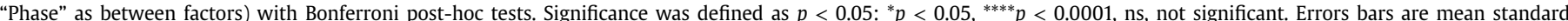

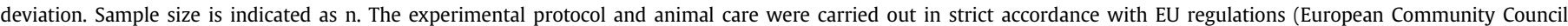

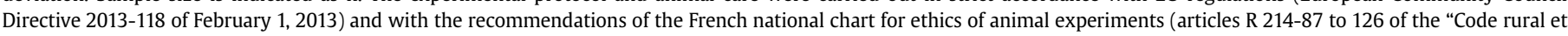

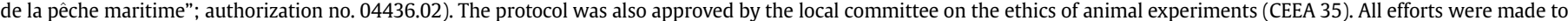
minimize animal suffering and to respect the concept of the 3Rs (Reduce, Refine, Replace).

Table 3

Central receptors and molecules of innate immunity and their effects (data adapted from Ref. [4]).

\begin{tabular}{|c|c|c|c|c|c|c|}
\hline PRRs $^{\text {a }}$ & Neuron & Microglia & Astrocyte & Infectious agent & Signalling pathways & Secreted cytokines \\
\hline TLR1 & - & + & - & Bacteria & Myd88 & TNF $\alpha$, IL- $1 \beta$, IFN $\gamma$ \\
\hline TLR2 & - & + & + & Bacteria & Myd88 & TNF $\alpha$, IL- $1 \beta$, IFN $\gamma$ \\
\hline TLR3 & + & + & + & Bacteria-virus & TRIF & IFN $\alpha$, IFN $\beta$, TNF $\alpha$, IL-6 \\
\hline TLR4 & - & + & - & Bacteria-virus & Myd88 & $\mathrm{TNF} \alpha, \mathrm{IL}-1 \beta, \mathrm{IFN} \gamma$ \\
\hline TLR5 & - & + & - & Bacteria & Myd88 & TNF $\alpha, I L-1 \beta$, IFN $\gamma$ \\
\hline TLR6 & - & + & - & Bacteria-fungi & Myd88 & TNF $\alpha, I L-1 \beta, I F N \gamma$ \\
\hline TLR7 & + & + & - & Bacteria-virus & Myd88 & IFN $\alpha$, IFN $\beta$, TNF $\alpha$, IL- $1 \beta$ \\
\hline TLR8 & + & + & - & Bacteria-virus & Myd88 & TNF $\alpha$, IL-1 $\beta$, IFN $\gamma$ \\
\hline TLR9 & + & + & + & Bacteria-virus & Myd88 & IFN $\alpha$, IFN $\beta$, TNF $\alpha$, IL- $1 \beta$ \\
\hline Nod2 & + & + & & Bacteria & RIPK or RICK & TNF $\alpha$, IL- $1 \beta$, IL-6 \\
\hline TNF $\alpha \mathrm{R}$ & + & low & low & 1 & 1 & 1 \\
\hline IL-1R & + & + & + & 1 & 1 & 1 \\
\hline IL-6R & low & low & low & 1 & 1 & 1 \\
\hline IFN $\alpha$ R & + & + & + & 1 & 1 & 1 \\
\hline IFN $\gamma \mathrm{R}$ & + & + & + & 1 & 1 & 1 \\
\hline
\end{tabular}

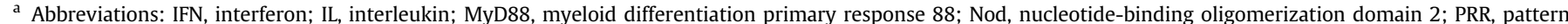

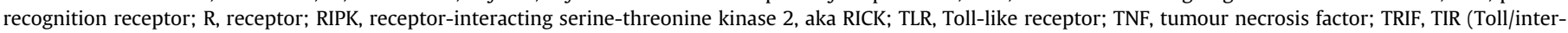
leukine-1 receptor-like) domain-containing adaptor-inducing interferon- $\beta$. 


\subsection{Inflammation mechanism}

Inflammation is not synonymous to infection; its understanding requires distinction between innate and adaptive immune reactions, which are functionally intertwined [51]. Inflammation is the innate system's response to fight infection. It is boosted by cytokines released by sentinel cells. This secretion and the resulting activation of $\mathrm{NF}_{\mathrm{K}} \mathrm{B}$ upregulate cytokines and O\&NS pathways, which in turn upregulate $\mathrm{NF}_{\mathrm{K}} \mathrm{B}$, perpetuating chronic inflammation process and immune activation via TLRs. As aggravating factors, O\&NS may generate redox-derived DAMPs, further leading to activation of $\mathrm{NF}_{\mathrm{K}} \mathrm{B}$ and cytokines. Thus, chronic inflammation and immune activation can be prolonged and even heighten by engagement of TLRs and DAMPs [52].

Bacterial, viral, parasitic and fungal infectious agents are able to trigger autoimmunity (the pathogen must be present to initiate the disease), activate autoimmunity in genetically-predisposed subjects (the pathogen is not essential but its presence precipitates or aggravates the pathology), or even they can impede autoimmunity [53]. Hypotheses linking infection and autoimmunity have been formulated, and five major mechanistic lines have emerged. They include molecular mimicry, 'epitope spreading' [i.e. diversification of the immune response (e.g. B- and T-cells, Abs) following initiation of immunity to a single or few foreign or self-components], bystander activation, polyclonal activation of lymphocytes, and a mechanism in which bacteria and viruses produce super-antigens (Table 4) [54]. Viruses may also activate intracellular TLRs through intracellular signalling pathways, inducing expression of type 1 IFN genes, leading to the typical 'interferon signature' described in lupus [55].

Viral or bacterial infections take part in lupus disease development by inducing cellular debris, which activate B-cells, or promoting autoAbs production. Thus, infections by cytomegalovirus, Parvovirus B19 and Epstein-Barr virus (EBV) are frequently cited in the production of favourable immune conditions allowing autoimmune phenomena, or as breakers of immune tolerance to selfmolecules. Molecular mimicry could be one mechanism responsible for the generation of lupus autoAbs and data obtained with EBV are particularly relevant [56]. Interestingly, an association between high titres of EBV Abs and skin and joint symptoms, but not with NP manifestations, have been found in lupus patients [57].

\subsection{At the CNS level: cells in the brain parenchyma}

In the CNS, the main cell types are neurons and glial cells (monocyte origin), which are further distinguished between microglial and macroglial cells (e.g. astrocytes, oligodendrocytes). Astrocytes are star-shaped glial cells providing mechanical and metabolic support for neurons, thereby regulating the external chemical environment by removing excess ions and recycling neurotransmitters. They respond to pathological changes with hypertrophy and hyperplasia, and are also essential for the integrity of the BBB, acting as filtres. With microglial cells, they are the brainresident macrophages, being actively involved in immune defence [58]. They regulate and limit inflammatory processes [59] through different mechanisms [e.g. production of anti-inflammatory molecules, expression of receptors (e.g. PRRs, receptors for cytokines and growth factors that are released by damaged neurons, receptors critical for antigen presentation)]. Microglial cells migrate into CNS during development, where they continue to expand specifically after trauma (being able to be directly activated by PAMPS and DAMPS) in which case they react by displaying morphological and functional changes (Fig. 3) with central proinflammatory cytokine expression (Table 3). Microglial cells are critical in both neuronal protection and pathology [60]. They notably produce neurotrophic substances crucial for cellular repair and recruitment of immune cells capable of eliminating pathogens or cell debris from the CNS. Increased microglial activation is related to both exaggerate production of proinflammatory molecules and neurodegenerative process [61]. According to the classification of microglia, M1-polarised microglia are prone to produce proinflammatory cytokines, reactive oxygen species (ROS) and nitric oxide (NO), whereas M2 cells rather inhibit inflammation and reinstate homeostasis [62]. Microglia would be polarised to M1 type in high-anxiety inbred mice, especially after a peripheral innate immune challenge, revealing thus potential molecular mechanisms of how anxiety might regulate microglial activation and polarization [63]. In SLE, even if reactive microglia has been observed in patients suffering from CNS troubles [64], the role of microglia remains to be deeply characterised. In lupus-prone mice, microglia activation and cytoplasm condensation suggest metabolic perturbations, which lead to dysfunction as well as early neuronal death [65]. In this complex scenario, infections seem to play a major, possibly triggering, role. Microglia is also an essential element of a competent BBB, which permit crosstalk between peripheral and CNS immune activities [66]. Centrally, neurons and astrocytes are generally not activated by PAMPs. The lack of most of the bacterial TLRs on neurons suggests that the consequences of a bacterial infection on behaviour are secondary to activation of other CNS cells, primary microglia (Table 3) [4].

\section{Inflammation-induced behaviour}

Circulating cytokines and proinflammatory molecules affect the CNS through neural and humoral circuits [67]; the neural circuit is related to afferent nerves, while the humoral pathway is mostly

Table 4

Main mechanisms used by pathogens for the activation of autoreactive T and B-cells (adapted from Refs. [54,147]).

\begin{tabular}{|c|c|}
\hline Mechanism & Actions \\
\hline Molecular mimicry & Microbial pathogens displaying structural resemblance with self-peptides activate autoreactive T and B-cells \\
\hline Epitope spreading & $\begin{array}{l}\text { Microorganisms specific to TH1 cells }{ }^{\mathrm{a}} \text { are activated, leading to release of self-peptides, which are further engulfed by APCs and exposed to } \\
\text { self-reactive TH1 cells }\end{array}$ \\
\hline Bystander activation & The production of cytokines is amplified, which induces expansion of autoreactive T-cells at an inflammatory site \\
\hline Polyclonal activation & Lymphotropic viruses stimulate lymphocytes, resulting in increased Abs production and ICs in the circulation \\
\hline $\begin{array}{l}\text { Bacterial and viral super- } \\
\text { antigens }\end{array}$ & Microorganisms produce proteins, which through binding to TCR and MHCII, activate numerous T-cells of different antigenic specificity \\
\hline Alteration of apoptosis & $\begin{array}{l}\text { Non-ingested nuclear elements supply survival cues for autoreactive B-cells, this resulting to Abs production against exposed nuclear } \\
\text { features }\end{array}$ \\
\hline Deficits of the immunity & Defect of the complement leads to decreased and inadequate clearance of infectious substances \\
\hline IFN signature & Activation of intracellular receptors (TLRs) via intracellular pathways leads to expression of type 1 IFN genes \\
\hline
\end{tabular}

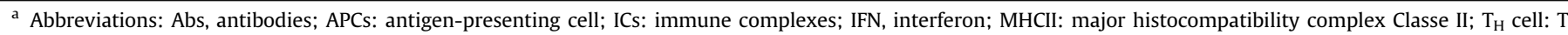
helper cell; TLRs, Toll-like receptors; TCR, T-cell receptor. 


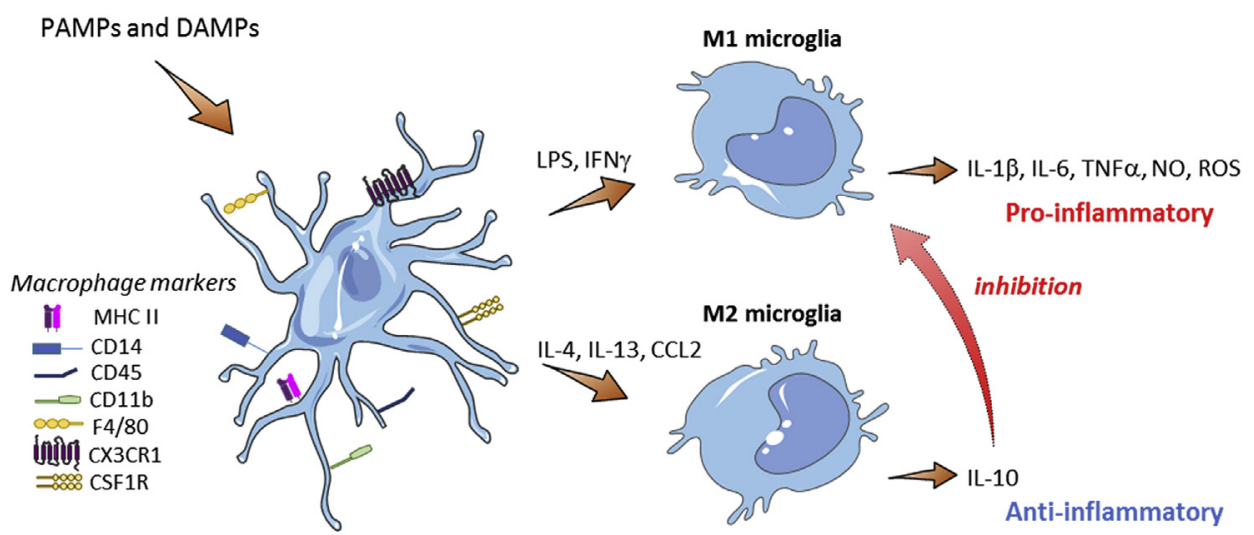

Microglial cells (normal resting state)
with long and branched cellular processes

Amoeboid microglia (reactive state) retractation of cellular processes

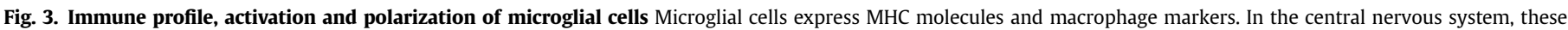

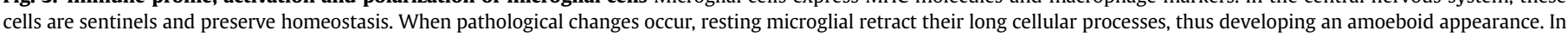

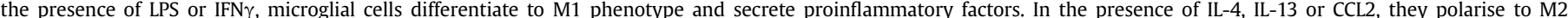

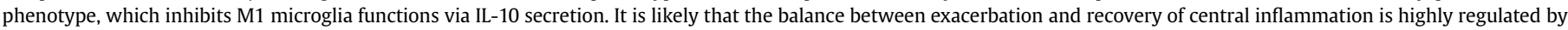

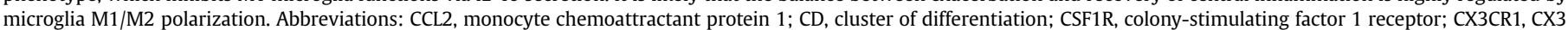

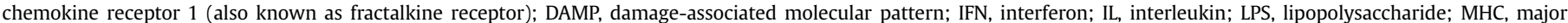

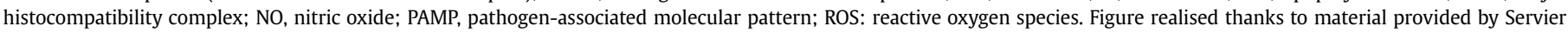
Medical Art (www.servier.fr) under the CC 3.0 FR license.

related to the $\mathrm{BBB}$, which regulates efflux of elements from the blood to the CNS, and then protects the brain from blood-borne pathogens [68].

\subsection{BBB: its compromise in neuroinflammation}

The BBB is a selectively permeable barrier formed by astrocytes and capillary endothelial cells connected by tight junctions, which restricts passage of small molecules into the brain. Part of the innate immune defence against pathogens entering the CNS is achieved by the BBB. When systemic inflammation occurs, as in SLE-related neuropathology, the permeability of the BBB increases $[68,69]$. Different cases of blood-to-brain signalling have been reported [70]. For example, peripheral inflammation induced by LPS directly provokes release of proinflammatory factors, activation of brain ECs, which further leads to upregulation of cell adhesion molecules, destabilization of tight junctions, thereby weakening BBB integrity [71]. After sepsis induction in mice, the BBB becomes rapidly leaky $(24 \mathrm{~h})$ with dramatic neuronal degeneration [72]. Following peripheral LPS challenge, brain region-specific upregulation of gene coding for several cytokines (IL-1 $\beta$, IL-6), glial fibrillary acidic protein and immune cell markers are also observed, demonstrating that cortical inflammation and glial stimulation arise in the context of peripheral inflammation [73,74]. In mice, even a single injection of a low LPS dose $(5 \mathrm{mg} / \mathrm{kg})$ generates longlasting affective modifications as diminution of exploratory ambulation and increase in depressive- and anxiety-like behaviours [75]. Similarly, in rats, LPS administered once is followed by prolonged neuroinflammation [76].

\subsection{Cytokines and NP manifestations}

Abnormal levels of circulating cytokines evidence chronic inflammation and immune activation, and is commonly observed in lupus [77]. In human and murine lupus, cytokines play an active role in the pathophysiology of the disease, contributing to the production of pathogenic autoAbs and to depression and sickness behaviour [78]. Furthermore, via their action on TLRs, cytokines are thought to impair hippocampal neurogenesis [79], which is an important mechanism in depression [80].

Cytokines acting on the brain proceed either peripherally or centrally [47]. From the periphery, cytokines enter the brain by different ways, including (i) cytokine passage through leaky BBB regions, (ii) active transport via transport molecules, (iii) activation of ECs and perivascular macrophages, and (iv) binding to cytokine receptors present on afferent fibres (the vagus nerve) [81]. At the $\mathrm{BBB}$ interface, $\mathrm{NF}_{\mathrm{K}} \mathrm{B}$ is pivotal to transmit signals. In rodent, it was demonstrated that inhibiting central $\mathrm{NF}_{\mathrm{K}} \mathrm{B}$ activity prevents activation of c-fos in different cerebral areas and accelerates recovery from LPS- and IL-1 $\beta$-induced sickness [82,83].

Cytokines produced centrally by astrocytes and microglia directly contribute to vasculopathy of focal ischemic and haemorrhagic brain disease. In lupus, several reports demonstrated that deregulated secretion of cytokines happens within the CNS, as IL-1, IL-6, IL-8, IFN $\alpha$, APRIL or BAFF, are found in the CSF of NPSLE patients $[84,85]$. IL-6 is commonly associated with SLE, inflammatory and neurological states, cerebrovascular disease, as well as depressive events [86]. Thus, activation of IL- 6 and $\mathrm{NF}_{\mathrm{K}} \mathrm{B}$ pathway is linked to deregulated sleep in depressed patients [87]. The BBB integrity and intrathecal IgG synthesis levels are classically evaluated by IgG index and Q-albumin test, respectively [70]. As such, the fact that IL-6 CSF levels are associated with IgG index implies that increased intrathecal IL- 6 may enhance B-cell responses within the CNS [88]. In addition to IL-6, IFN $\alpha$ is another cytokine that is associated with several NP symptoms in SLE and whose secretion is stimulated by ICs resulting from the binding of CSF autoAbs to antigens released by neurocytotoxic Abs [89].

Cytokine inducers (e.g. LPS, vaccination) can also cause behavioural manifestations overlapping those reported in depression. Then, LPS-administered healthy volunteers display acute anxiety and depressive behaviour and, as well, injection of a Salmonella typhi vaccine to healthy persons results in fatigue, depression, cognitive difficulty and psychomotor slowing [90,91]. The complex molecular and mechanistic interplay between neuroinflammation and infection in a context of autoimmunity has immediate consequences in clinical terms. 


\section{Link with neurodegeneration}

Under systemic inflammatory conditions, as those occurring during NPSLE, several mechanisms may activate neuroinflammation and neurodegeneration. Thus, due to increased permeability of the BBB, peripheral immune cells and inflammatory factors penetrate in the CNS where they provoke several reactive phenomena, including (i) astrogliosis (also known as reactive astrocytosis), which is an aberrant augmentation of the astrocytes density inducing diminution of synaptic maintenance, (ii) damages of myelin sheaths, which cause demyelination and axonal degeneration, and (iii) microgliosis, which usually involves hypertrophy and proliferation, and generates a proinflammatory phenotype of microglial cells with diminution of phagocytic and tissue homeostasis function (Fig. 4).

Cerebral perturbations can be direct effects of soluble factors or may be indirectly linked to reactive astrocytic and microglial responses. Data demonstrated that LPS activates microglial cells and contributes to cognitive dysfunction via an IL-1-dependent process; thus, the blockage of IL-1 signalling weakens the LPS inflammatory cascade, thereby attenuating microglial activation and hampering behavioural abnormalities [92].

\section{CNS normal conditions}

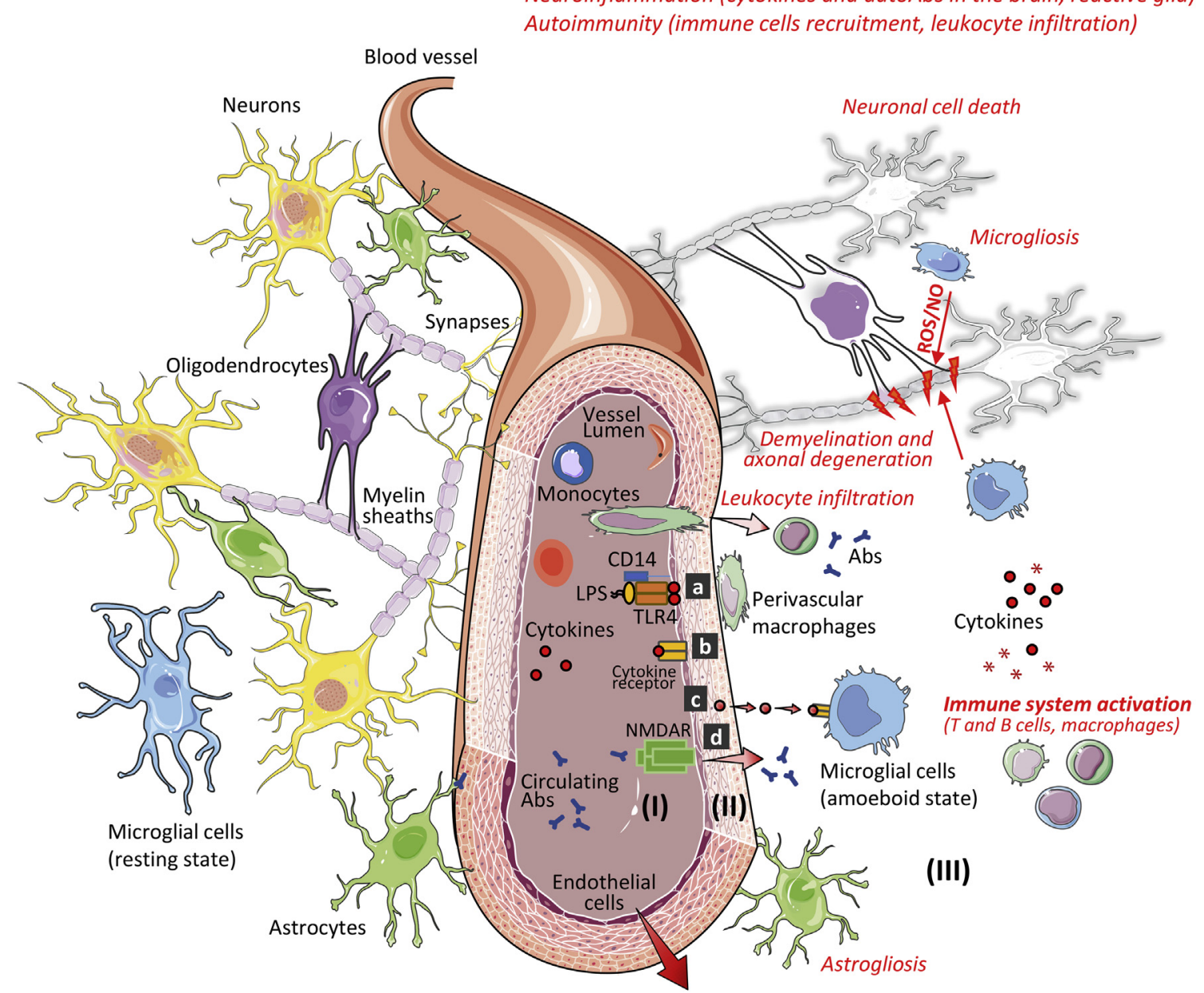

\section{CNS suffering conditions with BBB disruption}

Neuroinflammation (cytokines and autoAbs in the brain, reactive glia) Autoimmunity (immune cells recruitment, leukocyte infiltration)
Vascular endothelium with non-disrupted tight junctions
Vascular endothelium with disrupted tight junctions (allows penetration and diffusion of cytokines and small molecules into the CNS)

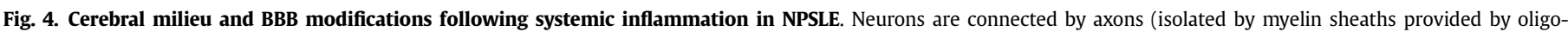

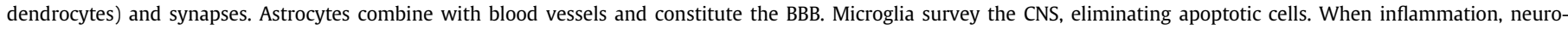

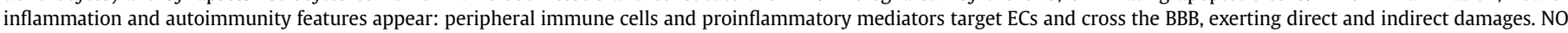

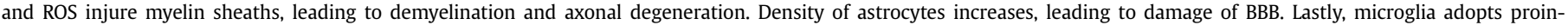

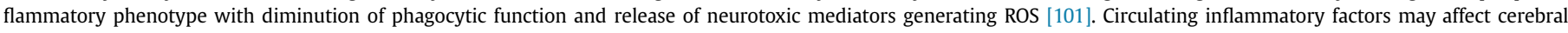

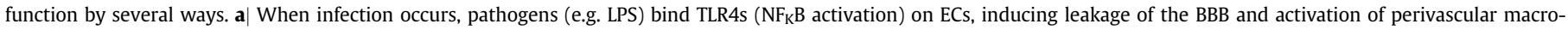

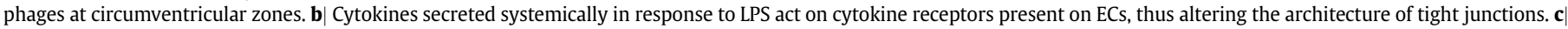

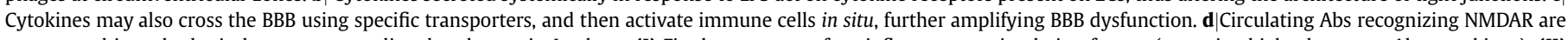

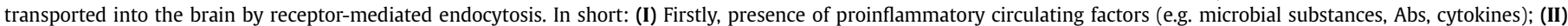

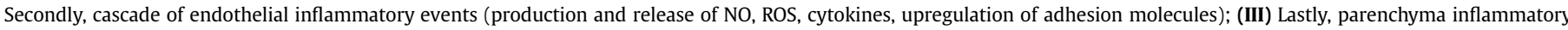

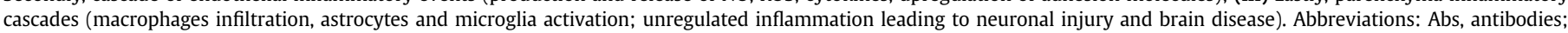

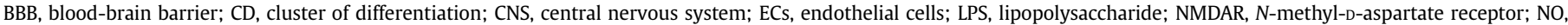

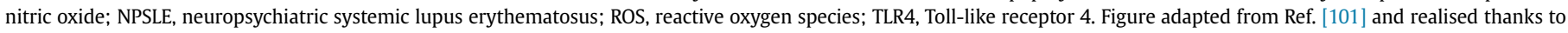
material provided by Servier Medical Art (www.servier.fr) under the CC 3.0 FR license. 
Immune control of the CNS and regulation of neuroinflammation are provided by brain microglia and peripheral immune cells [93-95]. The total elimination of infectious agents during cerebral infection generally entails irreversible cerebral tissue shrinkage, which however may be counteracted by processes of pathogen tolerance, as exemplified with HSV [96].

\subsection{Caspases in neurodegeneration and inflammation}

An important trigger for neurodegenerative processes is apoptosis. Under physiological conditions, apoptosis constantly occurs and cell fragments are removed without release of inflammatory mediators [97]. During systemic inflammation, such as lupus-related neuropathology, apoptosis of stressed cells but also pyroptosis, which is a form of programmed cellular death linked to antimicrobial response, might further exacerbate the underlying pathology [98]. Directly and indirectly, apoptosis stimulates caspases, which are effectors of apoptosis but are also important for initiating innate immune response through inflammasome [99], a multiprotein complex expressed in myeloid cells, thereby constituting essential element of the innate immune system, which cleaves pro-interleukin into proinflammatory cytokines (Il-1 $\beta$, IL18) and induces pyroptosis. Nowadays, data extend the role of caspases relating neuroinflammation to neurodegenerative processes $[100,101]$. Caspases activation has also a crucial role in lupus, as they can cleave self-proteins leading to fragments (some of which encompass apoptosis-specific post-translational modifications) that can be potent immunogens [102].

\subsection{Immune cells, AutoAbs, and neuroimmunology}

Proinflammatory cytokines, reactive oxygen species (ROS) and activated immune cells directly trigger apoptosis of central neurons [103]. Similarly, anti-brain Abs, such as anti-NMDAR Abs, can drive cerebral pathology further affecting behaviour and cognition, as described in SLE [104,105].

In NPSLE patients, the pathogenicity of CSF IgG Abs to NR2 subunit has been published both in vitro and in vivo [26,33]. Patientderived NMDAR Abs mediate persistent cognitive impairment as well as neuronal damage the hippocampus, which in one cerebral area crucially implicated in learning and memory process, of mice [27]. Structural abnormalities and hypermetabolism have also been similarly evidenced in the hippocampus of NPSLE patients [49,105]. All these findings, and others published more recently in NPSLE patients, suggest that NMDAR Abs are directly implicated in neurodegeneration [34,105]. Recently, authors proposed that anti-NR2 Abs and $\mathrm{NF}_{\mathrm{K}} \mathrm{B}$ activation may generate NPSLE pathogenesis [28]. An observation that may be highly relevant concerning reversibility of symptoms is that depending on their concentration, NMDAR Abs may either induce neuronal perturbation by transitory increment of excitatory postsynaptic potentials, or provoke neuronal death $[101,106]$.

Synaptic autoimmunity is currently an exciting burgeoning field of research. The identification of neurological syndromes, particularly encephalitis, associated with autoAbs reacting with extracellular epitopes of synaptic receptors and constituents of transsynaptic protein complexes $[107,108]$ displays determinant interest, extending and re-questioning classical concepts of neuroscience, neurology and psychiatry $[109,110]$. Targeted antigens that include NMDAR, alpha-amino-3-hydroxy-5-methyl-4isoxazolepropionic acid receptor (AMPAR), inhibitory gammaaminobutyric acid $B$ receptor $\left(G A B A_{B} R\right)$ or the glycine receptor (GlyR) are all essential actors of synaptic transmission, plasticity and nerve excitability. Other autoantigens are also implicated in mechanisms such as the secreted neuronal protein leucine-rich glioma-inactivated-1 (LGl1), contactin-associated protein-like 2 (Caspr2) and the intracellular enzyme glutamate decarboxylase (GAD). Clinical expression of these immune reactions is described in Table 5. In the past, these syndromes were considered as idiopathic or of unknown viral cause, and were designated with descriptive terms (i.e. dyskinetic encephalitis lethargica) [111]. The most extensively described neuronal cell surface Abs are here again NMDAR-Abs of individuals suffering from anti-NMDAR encephalitis. At the beginning, and due to its high relation with teratoma, anti-NMDAR encephalitis was categorised as a paraneoplastic syndrome [112]. However, a growing set of clinical evidence proposes that it may be rather considered as a neuroimmune disorder, where Abs are expressed following several signals (infection, tumour) and bind to synaptic proteins and NMDAR [113]. These Abs recognise NR1 subunit of the NMDAR, cross-react and internalise the receptor, thus decreasing the receptor density, and impairing neuronal functioning $[109,114]$. Autophagy may be another mechanism of action of these autoAbs; in this case, the process of degradation of NMDAR is comparable to that described in the case of acetylcholine receptors in myasthenia gravis [115]. It is important not to confuse NMDAR-Abs, which are greatly specific for antiNMDAR encephalitis, with NMDAR autoAbs detected in SLE individuals that recognise a linear epitope of the NR2A and B subunits of the NMDAR [109].

\section{Implication for the treatment}

For the last few decades, SLE patients are living significantly longer in developing countries thanks to both earlier diagnosis and administration of high doses of glucocorticoids or other cytotoxic/ immunosuppressive agents [116]. However, although such drastic treatments have lowered the mortality rate, we noticed that drug side effects, especially infections (e.g. bacterial sepsis, mycobacterial infection recrudescence, fungal and viral infection and/or reactivation, in some cases with dramatic consequences such as virus-induced malignancies) have been described in lupus patients [117-119]. This increased risk is linked to the disease itself (Table 6), but also to immunosuppressive treatment the patients receive to reduce some of their inflammatory symptoms and pain. Potentially, immunosuppressive therapy could also affect the ability of treated patients to behave appropriately to preventive vaccination. At least in part, this legitimate concern can be discarded, as there is no objective evidence, in large case reports, that vaccination causes lupus flares when killed vaccines are used [e.g. influenza, pneumococcal and hepatitis B (HBV) vaccines]. In general, however, live vaccines (e.g. varicella, measles, and rubella) are not recommended due to the potentiated infection risk from the vaccine, and should be preferably replaced by killed vaccines since the latter are available. It is also recommended that patients with lupus get vaccination outside active episodes of their disease and following careful consideration of their individual medication usage [120-122]. Some cases of flares have been described after vaccination against HBV, papillomavirus and norovirus. In summary, however, only few vaccines are unsafe in lupus patients. When carefully managed, vaccination is even particularly encouraged as it may significantly decrease the mortality in SLE population.

Nowadays, as infections are the main causes of morbidity and mortality in SLE [123-125], management and prevention of infections arise of greater importance [126]. In addition to adapted strategies of vaccination described above, there is an urgent need to replace immunosuppressive drugs by molecules that will modulate the autoimmune response without affecting the whole immune system $[127,128]$. This challenge appears set to be successful with the P140 synthetic peptide (also known as LupuzorTM), which corresponds to a sequence of the $\mathrm{U} 1-70 \mathrm{~K}$ spliceosomal protein. This 
Table 5

Encephalitis related to major Abs $^{\mathrm{a}}$ to neuronal cell surface antigens and their clinical characteristics (adapted from Refs. [3,107,109,148-151]).

\begin{tabular}{|c|c|c|c|c|c|c|}
\hline & NMDAR & AMPAR & $\mathrm{GABA}_{\mathrm{B}} \mathrm{R}$ & GlyR & LGI1 & Caspr2 \\
\hline Gender & Female (80\%) & Female (90\%) & Female (50\%) & Male (60\%) & Male (65\%) & Male (85\%) \\
\hline $\begin{array}{l}\text { Age } \\
\qquad(\text { median })\end{array}$ & 21 yrs & 60 yrs & $62 \mathrm{yrs}$ & 46 yrs & $60 \mathrm{yrs}$ & 60 yrs \\
\hline Symptoms & $\begin{array}{l}\text { Seizures; psychosis; abnormal } \\
\text { movements; language and } \\
\text { memory dysfunction; defect of } \\
\text { consciousness; } \\
\text { hypoventilation; breathing and } \\
\text { autonomic instability }\end{array}$ & $\begin{array}{l}\text { Seizures; agitation; } \\
\text { confusion; disorientation; } \\
\text { mood disorder; irritability; } \\
\text { short-term memory } \\
\text { dysfunction; psychosis; } \\
\text { limbic encephalitis }\end{array}$ & $\begin{array}{l}\text { Prominent seizures; memory } \\
\text { dysfunction; confusion; } \\
\text { disorientation; hallucination; } \\
\text { mood disorder; ataxia; } \\
\text { irritability; psychosis; limbic } \\
\text { encephalitis }\end{array}$ & $\begin{array}{l}\text { Progressive } \\
\text { encephalo- } \\
\text { myelitis with } \\
\text { rigidity and } \\
\text { myoclonus; } \\
\text { Stiffman } \\
\text { syndrome }\end{array}$ & $\begin{array}{l}\text { Tonic-myoclonic } \\
\text { seizures; limbic } \\
\text { encephalitis; } \\
\text { amnesia; apathy; } \\
\text { irritability; } \\
\text { confusion; } \\
\text { disorientation }\end{array}$ & $\begin{array}{l}\text { Encephalitis, } \\
\text { neuromyotonia, or both } \\
\text { (Morvan syndrome); } \\
\text { seizures; confusion; } \\
\text { amnesia; insomnia; } \\
\text { weight loss }\end{array}$ \\
\hline MRI & $\begin{array}{l}\text { Transient increase of FLAIR } \\
\text { signal in the cerebellar cortex } \\
\text { or in medial temporal lobes; } \\
\text { intracranial hypertension; } \\
\text { demyelination }\end{array}$ & $\begin{array}{l}\text { Increase of FLAIR signal in } \\
\text { medial temporal lobes }\end{array}$ & $\begin{array}{l}\text { Increase of FLAIR signal in } \\
\text { medial temporal lobes }\end{array}$ & Normal & $\begin{array}{l}\text { Increase of FLAIR } \\
\text { signal in medial } \\
\text { temporal lobes }\end{array}$ & $\begin{array}{l}\text { Increase of FLAIR signal in } \\
\text { medial temporal lobes } \\
\text { when encephalitis; } \\
\text { spontaneous muscular } \\
\text { hyperactivity (EMG) } \\
\text { when neuromyotonia }\end{array}$ \\
\hline Tumour & Ovarian teratoma in most cases & $\begin{array}{l}\text { Small cell lung carcinoma, } \\
\text { thymoma, breast cancer }\end{array}$ & Small cell lung carcinoma & $\begin{array}{l}\text { Thymoma; } \\
\text { Hodgkin } \\
\text { lymphoma }\end{array}$ & Thymoma (rare) & $\begin{array}{l}\text { Limited data: probably } \\
\text { thymoma }\end{array}$ \\
\hline CSF & $\begin{array}{l}\text { Lymphocytosis; increased } \\
\text { protein level; CSF-specific } \\
\text { oligoclonal bands; frequent } \\
\text { intrathecal Abs synthesis }\end{array}$ & $\begin{array}{l}\text { Lymphocytosis; increased } \\
\text { protein level; CSF-specific } \\
\text { oligoclonal bands; frequent } \\
\text { intrathecal Abs synthesis }\end{array}$ & $\begin{array}{l}\text { Lymphocytosis; increased } \\
\text { protein level; CSF-specific } \\
\text { oligoclonal bands; constant } \\
\text { intrathecal Abs synthesis }\end{array}$ & $\begin{array}{l}\text { Usually normal; } \\
\text { occasional mild } \\
\text { lymphocytosis }\end{array}$ & $\begin{array}{l}\text { Infrequent } \\
\text { intrathecal Abs } \\
\text { synthesis }\end{array}$ & $\begin{array}{l}\text { Limited data concerning } \\
\text { intrathecal Abs synthesis }\end{array}$ \\
\hline Other Abs & 10\% (ANA, TPO) & $\begin{array}{l}\sim 60 \% \text { (ANA, TPO, GAD } 65 \\
\text { VGCC, SOX1, cardiolipin) }\end{array}$ & $\begin{array}{l}\text { 50\% (VGCC, GAD } 65, \text { TPO, } \\
\text { SOX1) }\end{array}$ & Unknown & $\begin{array}{l}\sim 10 \% \text { (ANA, TPO, } \\
\left.\text { GAD }_{65}\right)\end{array}$ & $\sim 20 \%$ MuSK; AChR, GAD 65 \\
\hline Outcomes & $\begin{array}{l}\text { Good when immunotherapy; } \\
\text { possible cognitive sequelae }\end{array}$ & Tendency to relapse & Good, with rare relapses & Good & $\begin{array}{l}\text { Good, or mild } \\
\text { sequelae }\end{array}$ & Limited data \\
\hline
\end{tabular}

a Abbreviations: Abs, antibodies; AChR, acetylcholine receptor; AMPAR, alpha-amino-3-hydroxy-5-methyl-4-isoxazolepropionic acid receptor; ANA, antinuclear Ab;

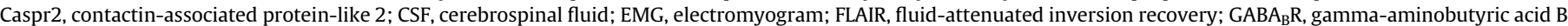

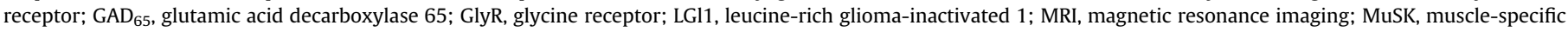
kinase; NMDAR, $N$-methyl-D-aspartate receptor; SOX1, sex determining region Y-box 1; TPO, thyroid peroxidase; VGCC, voltage-gated calcium channel; yrs, years.

peptide was chemically modified by inserting a phosphoserine residue at the position 140 , and only the modified peptide displays protective properties in a murine model of lupus [129]. In patients, P140/Lupuzor ${ }^{\mathrm{TM}}$ is well tolerated [130], non immunogenic [129], and a phase III-clinical study is currently in progress. In MRL/lpr lupus-prone mice, P140 binds HSPA8/HSC70 chaperone protein, decreases its expression and reduces autophagic flux in B lymphocytes of peptide-treated mice [131]. P140 interferes with chaperone-mediated autophagy (CMA) [132]. It induces lower expression of MHC-II molecules and alteration of peptides presentation to autoreactive T-cells, leading to a reduction of $\mathrm{T}$ and $\mathrm{B}-$ cells activation and a drop of potentially pathogenic autoAbs production. This process is without effect on the resistance of mice to infection by Flu virus, meaning that after P140 treatment, the overall immune system remains intact. Based on this unique selective inhibitory effect of P140 peptide on CMA, we anticipate that P140/Lupuzor may be efficient in several other pathological conditions in which activity of CMA is abnormally raised as is the case, particularly, in several neuroinflammatory diseases [132,133].

\section{Outstanding questions and future research}

Research is still at the beginning concerning how infectious pathogens are able to trigger, sustain, or exacerbate neuroinflammation and neurodegeneration, as well as concerning the precise role of T-cells in CNS homeostasis. Are these cells only pathogenic in being involved in CNS injury following infection and neurodegeneration? Or could certain T-cells subsets also be implicated in limiting neuroinflammation? A breakthrough would be to identify these T cell subsets.

Other questions remain open concerning CNS inflammatory responses in general, and NPSLE in particular; what about the precise role played by microglia? And what about "glial autophagy", as this mechanism may be essential to preserve cellular vesicles and proteins, notably mitochondrial architecture during inflammation in astrocytes, and as such, neuronal homeostasis? Is glial autophagy a target for specific therapy? Concerning therapy, which immune-based treatment should be investigated in neuropsychiatric autoimmune diseases to foster CNS repair? Are small

Table 6

Susceptibility factors for infections in lupus patients.

\begin{tabular}{ll}
\hline Genetically predisposing factors & Risk factors \\
\hline Genetic complement deficiency & Leucopenia \\
MBL $^{\mathrm{a}}$ deficiency & Functional hyposplenism \\
CRP deficiency & Hypogammaglobulinaemia \\
& Complement deficiency \\
& Corticosteroid use (prednisolone doses over 7.5-10 mg/day) ${ }^{\mathrm{b}}$ \\
& Immunosuppressive medication (e.g. cyclophosphamide ${ }^{\mathrm{b}}$, azathioprine, mycophenolate mofetil) \\
& Biologics (e.g., rituximab) \\
& High-dose chemotherapy \\
& Splenectomy \\
\hline
\end{tabular}

\footnotetext{
a Abbreviations: CRP, $\mathrm{C}$ reactive protein; MBL, mannose-binding lectin.

b The risk for developing infection is dose-dependent.
} 
molecules/peptides that target autophagy processes promising tools for treating patients with NPSLE and other NP autoimmune/ inflammatory diseases? Finally, how are autoimmunity, neurology, and psychiatry intertwined?

\section{Conclusions}

The etiology of autoimmune and NP diseases, especially NPSLE, is still fragmented and incomplete. Immunological, hormonal and environmental factors undoubtedly interact to induce disease in genetically-predisposed individuals. A disruption of BBB integrity caused by external factors, including infections, is a pivotal factor in the etiopathology of NPSLE in allowing the penetration of Abs into the brain and binding to cross-reactive epitopes.

There is much current interest in the idea that gut microbiota contributes to the autoimmune status of individuals and therefore to behavioural defect. This idea remains however difficult to analyze deeply in humans since the commensal microbiota can either be altered due to the disease itself or treatment. The use of animal models where the intestinal flora can be manipulated represents an experimental strategy of choice to investigate this central mechanistic question. Some studies have shown that, in patients suffering from myalgic encephalomyelitis/Chronic fatigue syndrome, translocation of bacterial LPS from the gut and engagement with TLRs (further acting as PAMPs) due to modification of intestinal permeability generated by molecules of chronic inflammation (cytokines, $\mathrm{NF}_{\mathrm{K}} \mathrm{B}, \mathrm{O} \& \mathrm{NS}$ ), may be source for fatigue and depression $[43,134,135]$.

The theory of "early-life programming of adult disease", which supposes that prenatally or early postnatally environmental factors lead to permanent modifications in physiology throughout life is now well accepted [136], and happens also for the immune system [137]. Then, prenatal maternal exposure of rats to LPS or IL-6 significantly increases central and peripheral proinflammatory mediators amounts, along with an increase of the microglial density in the progeny, which persist until adulthood $[138,139]$. Contact with infectious pathogens and/or immune activation early in life, may also raise the risk of developing NP disorders later. From a molecular point of view, data emphasise the role of prenatal cytokine-related inflammatory mechanisms in the mediation of maternal infection effects on the offspring; thus, both genetic and pharmacological blockage of IL-6 in murine pregnant maternal host, or a genetically-induced over-expression of IL-10, prevent the long-term deleterious effects of prenatal viral-like immune activation, both at the cerebral and behavioural levels [140].

Finally, historically considered as an immune-privilege site, the brain is presently viewed as being able to display immune reactions [141-144]. Indeed, the brain presents functional lymphatic vessels, located in the meninges, which remove fluid and immune cells. Then, dysfunction of this meningeal lymphatic system may drive numerous neurological and neuroinflammatory conditions (including NPSLE), in which modified immunity plays crucial role.

\section{Conflict of interest}

Both authors declare no financial conflict of interest.

\section{Author contribution}

Both authors wrote the article.

\section{Acknowledgements}

We are grateful to Marinos C. Dalakas (University of Athens Medical School, Neuroimmunology Unit, Dept of Pathophysiology,
Greece) and David A. Isenberg (University College Hospital, London, UK) for critical reading of the manuscript, to Viviane Pallage and Dominique Ciocca (Chronobiotron, UMS3415, French Centre National de la Recherche Scientifique/Université de Strasbourg, France) for help in behavioural study. Research in the SM's laboratory is financially supported by the French Centre National de la Recherche Scientifique, the Région Alsace, the Laboratory of Excellence Medalis (ANR-10-LABX-0034), and the EquipEx program I2MC (ANR-11-EQPX-022), Initiative of Excellence (IdEx), Strasbourg University.

\section{References}

[1] M. Hornig, The role of microbes and autoimmunity in the pathogenesis of neuropsychiatric illness, Curr. Opin. Rheumatol. 25 (2013) 488-795, http:// dx.doi.org/10.1097/BOR.0b013e32836208de.

[2] V. Bergink, S.M. Gibney, H.A. Drexhage, Autoimmunity, inflammation, and psychosis: a search for peripheral markers, Biol. Psychiatry 75 (2014) 324-331, http://dx.doi.org/10.1016/j.biopsych.2013.09.037.

[3] M.S. Kayser, J. Dalmau, The emerging link between autoimmune disorders and neuropsychiatric disease, J. Neuropsychiatry Clin. Neurosci. 23 (2011) 90-97, http://dx.doi.org/10.1176/appi.neuropsych.23.1.90.

[4] R.H. McCusker, K.W. Kelley, Immune-neural connections: how the immune system's response to infectious agents influences behavior, J. Exp. Biol. 216 (2013) 84-98, http://dx.doi.org/10.1242/jeb.073411.

[5] N. Danchenko, J.A. Satia, M.S. Anthony, Epidemiology of systemic lupus erythematosus: a comparison of worldwide disease burden, Lupus 15 (2006) $308-318$.

[6] C. Ohnmacht, J.-H. Park, S. Cording J.B. Wing, K. Atarashi, Y. Obata, et al. Mucosal immunology. The microbiota regulates type 2 immunity through ROR $\gamma \mathrm{t}^{+} \mathrm{T}$ cells, Science 349 (2015) 989-993, http://dx.doi.org/10.1126/ science.aac4263.

[7] S. O'Neill, R. Cervera, Systemic lupus erythematosus, Best. Pract. Res. Clin. Rheumatol. $24 \quad$ (2010) 841-855, http://dx.doi.org/10.1016/ j.berh.2010.10.006.

[8] A.E. Johnson, C. Gordon, R.G. Palmer, P.A. Bacon, The prevalence and incidence of systemic lupus erythematosus in Birmingham, England. Relationship to ethnicity and country of birth, Arthritis Rheum. 38 (1995) 551-558.

[9] L. Arnaud, J.-P. Fagot, A. Mathian, M. Paita, A. Fagot-Campagna, Z. Amoura, Prevalence and incidence of systemic lupus erythematosus in France: a 2010 nation-wide population-based study, Autoimmun. Rev. 13 (2014) 1082-1089, http://dx.doi.org/10.1016/j.autrev.2014.08.034.

[10] M. Koga, A. Kawasaki, I. Ito, T. Furuya, J. Ohashi, C. Kyogoku, et al., Cumulative association of eight susceptibility genes with systemic lupus erythematosus in a Japanese female population, J. Hum. Genet. 56 (2011) 503-507, http:// dx.doi.org/10.1038/jhg.2011.49.

[11] G. Zandman-Goddard, M. Solomon, Z. Rosman, E. Peeva, Y. Shoenfeld, Environment and lupus-related diseases, Lupus 21 (2012) 241-250, http:// dx.doi.org/10.1177/0961203311426568.

[12] J.G. Hanly, Attribution in the assessment of nervous system disease in SLE, Rheumatology 54 (2015) 755-756, http://dx.doi.org/10.1093/rheumatology/ keu458.

[13] E. Zirkzee, T. Huizinga, E. Bollen, Buchem M. van, H. Middelkoop, Wee N. van der, et al., Mortality in neuropsychiatric systemic lupus erythematosus (NPSLE), Lupus 23 (2014) 31-38, http://dx.doi.org/10.1177/ 0961203313512540.

[14] H. Jeltsch-David, S. Muller, Neuropsychiatric systemic lupus erythematosus: pathogenesis and biomarkers, Nat. Rev. Neurol. 10 (2014) 579-596, http:// dx.doi.org/10.1038/nrneurol.2014.148.

[15] G.K. Bertsias, C. Pamfil, A. Fanouriakis, D.T. Boumpas, Diagnostic criteria for systemic lupus erythematosus: has the time come? Nat. Rev. Rheumatol. 9 (2013) 687-694, http://dx.doi.org/10.1038/nrrheum.2013.103.

[16] E. Ercan, C. Ingo, O. Tritanon, C. Magro-Checa, A. Smith, S. Smith, et al., A multimodal MRI approach to identify and characterize microstructural brain changes in neuropsychiatric systemic lupus erythematosus, NeuroImage Clin. 8 (2015) 337-344, http://dx.doi.org/10.1016/j.nicl.2015.05.002.

[17] M. Piga, M.T. Peltz, C. Montaldo, D. Perra, G. Sanna, A. Cauli, et al., Twentyyear brain magnetic resonance imaging follow-up study in Systemic Lupus Erythematosus: factors associated with accrual of damage and central nervous system involvement, Autoimmun. Rev. 14 (2015) 510-516, http:// dx.doi.org/10.1016/j.autrev.2015.01.010.

[18] A. Zimny, M. Szmyrka-Kaczmarek, P. Szewczyk, J. Bladowska, A. PokryszkoDragan, E. Gruszka, et al., In vivo evaluation of brain damage in the course of systemic lupus erythematosus using magnetic resonance spectroscopy, perfusion-weighted and diffusion-tensor imaging, Lupus 23 (2014) 10-19, http://dx.doi.org/10.1177/0961203313511556.

[19] H. Ainiala, J. Loukkola, J. Peltola, M. Korpela, A. Hietaharju, The prevalence of neuropsychiatric syndromes in systemic lupus erythematosus, Neurology 57 (2001) 496-500.

[20] J.G. Hanly, M.B. Urowitz, L. Su, S.C. Bae, C. Gordon, D.J. Wallace, et al., Prospective analysis of neuropsychiatric events in an international disease 
inception cohort of patients with systemic lupus erythematosus, Ann. Rheum. Dis. 69 (2010) 529-535, http://dx.doi.org/10.1136/ard.2008.106351.

[21] J.I. Ellyard, R. Jerjen, J.L. Martin, A.Y.S. Lee, M.A. Field, S.H. Jiang, et al., Identification of a pathogenic variant in TREX1 in early-onset cerebral systemic lupus erythematosus by Whole-exome sequencing, Arthritis Rheumatol. 66 (2014) 3382-3386, http://dx.doi.org/10.1002/art.38824.

[22] J.G. Hanly, Diagnosis and management of neuropsychiatric SLE, Nat. Rev. Rheumatol. 10 (2014) 338-347, http://dx.doi.org/10.1038/nrrheum.2014.15.

[23] S. Kivity, N. Agmon-Levin, G. Zandman-Goddard, J. Chapman, Y. Shoenfeld, Neuropsychiatric lupus: a mosaic of clinical presentations, BMC Med. (2015) 13, http://dx.doi.org/10.1186/s12916-015-0269-8.

[24] J.G. Hanly, N.M. Walsh, V. Sangalang, Brain pathology in systemic lupus erythematosus, J. Rheumatol. 19 (1992) 732-741.

[25] M. Bravo-Zehnder, E.M. Toledo, F. Segovia-Miranda, F.G. Serrano, M.J. Benito, C. Metz, et al., Anti-ribosomal p protein autoantibodies from patients with neuropsychiatric lupus impair memory in mice, Arthritis Rheumatol. 67 (2015) 204-214, http://dx.doi.org/10.1002/art.38900.

[26] L.A. DeGiorgio, K.N. Konstantinov, S.C. Lee, J.A. Hardin, B.T. Volpe, B. Diamond, A subset of lupus anti-DNA antibodies cross-reacts with the NR2 glutamate receptor in systemic lupus erythematosus, Nat. Med. 7 (2001) 1189-1193, http://dx.doi.org/10.1038/nm1101-1189.

[27] C. Kowal, L.A. DeGiorgio, J.Y. Lee, M.A. Edgar, P.T. Huerta, B.T. Volpe, et al., Human lupus autoantibodies against NMDA receptors mediate cognitive impairment, Proc. Natl. Acad. Sci. 103 (2006) 19854-19859, http:// dx.doi.org/10.1073/pnas.0608397104.

[28] T. Yoshio, H. Okamoto, Pathogenesis of neuropsychiatric syndromes of systemic lupus erythematosus, Open J. Rheumatol. Autoimmune Dis. 5 (2015) 46-56, http://dx.doi.org/10.4236/ojra.2015.52009.

[29] Y. Arinuma, T. Yanagida, S. Hirohata, Association of cerebrospinal fluid anti-NR2 glutamate receptor antibodies with diffuse neuropsychiatric systemic lupus erythematosus, Arthritis Rheum. 58 (2008) 1130-1135, http:// dx.doi.org/10.1002/art.23399.

[30] H. Fragoso-Loyo, J. Cabiedes, A. Orozco-Narváez, L. Dávila-Maldonado, Y. Atisha-Fregoso, B. Diamond, et al., Serum and cerebrospinal fluid autoantibodies in patients with neuropsychiatric lupus erythematosus. Implications for diagnosis and pathogenesis, PLoS One 3 (2008) e3347, http:// dx.doi.org/10.1371/journal.pone.0003347.

[31] H.G. Bluestein, G.W. Williams, A.D. Steinberg, Cerebrospinal fluid antibodies to neuronal cells: association with neuropsychiatric manifestations of systemic lupus erythematosus, Am. J. Med. 70 (1981) 240-246.

[32] B. Diamond, P.T. Huerta, P. Mina-Osorio, C. Kowal, B.T. Volpe, Losing your nerves? Maybe it's the antibodies, Nat. Rev. Immunol. 9 (2009) 449-456, http://dx.doi.org/10.1038/nri2529.

[33] C. Kowal, L.A. DeGiorgio, T. Nakaoka, H. Hetherington, P.T. Huerta, B. Diamond, et al., Cognition and immunity: antibody impairs memory, Immunity 21 (2004) 179-188, http://dx.doi.org/10.1016/

34] X. Bosch, M. Ramos-Casals, M.A. Khamashta, The DWEYS peptide in systemic lupus erythematosus, Trends Mol. Med. 18 (2012) 215-223, http:// dx.doi.org/10.1016/j.molmed.2012.01.008.

[35] F. Segovia-Miranda, F. Serrano, A. Dyrda, E. Ampuero, C. Retamal, M. BravoZehnder, et al., Pathogenicity of lupus anti-ribosomal p antibodies: role of cross-reacting neuronal surface $\mathrm{p}$ antigen in glutamatergic transmission and plasticity in a mouse model, Arthritis Rheumatol. 67 (2015) 1598-1610, http://dx.doi.org/10.1002/art.39081.

[36] H. Fragoso-Loyo, Y. Richaud-Patin, A. Orozco-Narváez, L. Dávila-Maldonado, Y. Atisha-Fregoso, L. Llorente, et al., Interleukin-6 and chemokines in the neuropsychiatric manifestations of systemic lupus erythematosus, Arthritis Rheum. 56 (2007) 1242-1250, http://dx.doi.org/10.1002/art.22451.

[37] S. Hirohata, Y. Kanai, A. Mitsuo, Y. Tokano, H. Hashimoto, Accuracy of cerebrospinal fluid IL-6 testing for diagnosis of lupus psychosis. A multicenter retrospective study, Clin. Rheumatol. 28 (2009) 1319-1323, http:// dx.doi.org/10.1007/s10067-009-1226-8.

[38] H. Okamoto, A. Kobayashi, H. Yamanaka, Cytokines and chemokines in neuropsychiatric syndromes of systemic lupus erythematosus, BioMed Res. Int. (2010) 2010, http://dx.doi.org/10.1155/2010/268436.

[39] E. Trysberg, K. Blennow, O. Zachrisson, A. Tarkowski, Intrathecal levels of matrix metalloproteinases in systemic lupus erythematosus with central nervous system engagement, Arthritis Res. Ther. 6 (2004) R551-R556, http://dx.doi.org/10.1186/ar1228.

[40] J.G. Hanly, New insights into central nervous system lupus: a clinical perspective, Curr. Rheumatol. Rep. 9 (2007) 116-124.

[41] G. Wang, S.S. Pierangeli, E. Papalardo, G. a. S. Ansari, M.F. Khan, Markers of oxidative and nitrosative stress in systemic lupus erythematosus: correlation with disease activity, Arthritis Rheum. 62 (2010) 2064-2072, http:// dx.doi.org/10.1002/art.27442.

[42] G.E. Hodes, V. Kana, C. Menard, M. Merad, S.J. Russo, Neuroimmune mechanisms of depression, Nat. Neurosci. 18 (2015) 1386-1393, http://dx.doi.org/ 10.1038/nn.4113.

[43] G. Morris, M. Berk, K. Walder, M. Maes, Central pathways causing fatigue in neuro-inflammatory and autoimmune illnesses, BMC Med. 13 (2015) 28, http://dx.doi.org/10.1186/s12916-014-0259-2.

[44] M. Gibertini, C. Newton, H. Friedman, T.W. Klein, Spatial learning impairment in mice infected with Legionella Pneumophila or administered exogenous interleukin-1-beta, Brain Behav. Immun. 9 (1995) 113-128.
[45] S. Kent, R.M. Bluthé, K.W. Kelley, R. Dantzer, Sickness behavior as a new target for drug development, Trends Pharmacol. Sci. 13 (1992) 24-28.

[46] T.J. Santoro, M. Tomita, S.J. Larson, The potential impact of sicknessmotivated behavior on the expression of neuropsychiatric disturbances in systemic lupus erythematosus, Med. Hypotheses 69 (2007) 502-507, http:// dx.doi.org/10.1016/j.mehy.2007.01.033.

[47] M. Tomita, R.L. Khan, B.H. Blehm, T.J. Santoro, The potential pathogenetic link between peripheral immune activation and the central innate immune response in neuropsychiatric systemic lupus erythematosus, Med. Hypotheses 62 (2004) 325-335, http://dx.doi.org/10.1016/j.mehy.2003.10.009.

[48] D.A. Ballok, J. Woulfe, M. Sur, M. Cyr, B. Sakić, Hippocampal damage in mouse and human forms of systemic autoimmune disease, Hippocampus 14 (2004) 649-661, http://dx.doi.org/10.1002/hipo.10205.

[49] S. Appenzeller, A.D. Carnevalle, L.M. Li, L.T.L. Costallat, F. Cendes, Hippocampal atrophy in systemic lupus erythematosus, Ann. Rheum. Dis. 65 (2006) 1585-1589, http://dx.doi.org/10.1136/ard.2005.049486.

[50] T.S. van Kempen, M.H. Wenink, E.F.A. Leijten, T.R.D.J. Radstake, M. Boes, Perception of self: distinguishing autoimmunity from autoinflammation, Nat. Rev. Rheumatol. 11 (2015) 483-492, http://dx.doi.org/10.1038/ nrrheum.2015.60.

[51] A. Waisman, R.S. Liblau, B. Becher, Innate and adaptive immune responses in the CNS, Lancet Neurol. 14 (2015) 945-955, http://dx.doi.org/10.1016/ S1474-4422(15)00141-6.

[52] K. Lucas, M. Maes, Role of the Toll like receptor (TLR) radical cycle in chronic inflammation: possible treatments targeting the TLR4 pathway, Mol. Neurobiol. 48 (2013) 190-204, http://dx.doi.org/10.1007/s12035-013-8425-7.

[53] A.V. Chervonsky, Influence of microbial environment on autoimmunity, Nat. Immunol. 11 (2010) 28-35, http://dx.doi.org/10.1038/ni.1801.

[54] D. Rigante, M.B. Mazzoni, S. Esposito, The cryptic interplay between systemic lupus erythematosus and infections, Autoimmun. Rev. 13 (2014) 96-102, http://dx.doi.org/10.1016/j.autrev.2013.09.004.

[55] J. Banchereau, V. Pascual, Type I interferon in systemic lupus erythematosus and other autoimmune diseases, Immunity 25 (2006) 383-392, http:// dx.doi.org/10.1016/j.immuni.2006.08.010.

[56] A. Sabbatini, S. Bombardieri, P. Migliorini, Autoantibodies from patients with systemic lupus erythematosus bind a shared sequence of SmD and EpsteinBarr virus-encoded nuclear antigen EBNA I, Eur. J. Immunol. 23 (1993) 1146-1152, http://dx.doi.org/10.1002/eji.1830230525.

[57] G. Zandman-Goddard, Y. Berkun, O. Barzilai, M. Boaz, M. Blank, M. Ram, et al. Exposure to Epstein-Barr virus infection is associated with mild systemic lupus erythematosus disease, Ann. N. Y. Acad. Sci. 1173 (2009) 658-663, http://dx.doi.org/10.1111/j.1749-6632.2009.04754.x.

[58] M. Prinz, J. Priller, Microglia and brain macrophages in the molecular age: from origin to neuropsychiatric disease, Nat. Rev. Neurosci. 15 (2014) 300-312, http://dx.doi.org/10.1038/nrn3722.

[59] A. Shemer, D. Erny, S. Jung, M. Prinz, Microglia plasticity during health and disease: an immunological perspective, Trends Immunol. 36 (2015) 614-624.

[60] S. Robel, H. Sontheimer, Glia as drivers of abnormal neuronal activity, Nat. Neurosci. 19 (2015) 28-33, http://dx.doi.org/10.1038/nn.4184.

[61] M.L. Block, L. Zecca, J.-S. Hong, Microglia-mediated neurotoxicity: uncovering the molecular mechanisms, Nat. Rev. Neurosci. 8 (2007) 57-69, http:// dx.doi.org/10.1038/nrn2038.

[62] Y. Nakagawa, K. Chiba, Role of microglial $\mathrm{m} 1 / \mathrm{m} 2$ polarization in relapse and remission of psychiatric disorders and diseases, Pharmaceuticals 7 (2014) 1028-1048, http://dx.doi.org/10.3390/ph7121028.

[63] Z. Li, L. Ma, N. Kulesskaya, V. Võikar, L. Tian, Microglia are polarized to M1 type in high-anxiety inbred mice in response to lipopolysaccharide challenge, Brain Behav. Immun. 38 (2014) 237-248, http://dx.doi.org/10.1016/ j.bbi.2014.02.008.

[64] Z.S. Meszaros, A. Perl, S.V. Faraone, Psychiatric symptoms in systemic lupus erythematosus, J. Clin. Psychiatry 73 (2012) 993-1001, http://dx.doi.org/ 10.4088/JCP.11r07425.

[65] D.A. Ballok, X. Ma, J.A. Denburg, L. Arsenault, B. Sakić, Ibuprofen fails to prevent brain pathology in a model of neuropsychiatric lupus, J. Rheumatol. 33 (2006) 2199-2213.

[66] J. Correale, A. Villa, Cellular elements of the blood-brain barrier, Neurochem. Res. 34 (2009) 2067-2077, http://dx.doi.org/10.1007/s11064-009-0081-y.

[67] J. Ordovas-Montanes, S. Rakoff-Nahoum, S. Huang, L. Riol-Blanco, O. Barreiro, U.H. Van Andrian, The regulation of immunological processes by peripheral neurons in homeostasis and disease, Trends Immunol. 36 (2015) 578-604.

[68] Z. Zhao, A.R. Nelson, C. Betsholtz, B.V. Zlokovic, Establishment and dysfunction of the blood-brain barrier, Cell 163 (2015) 1064-1078, http:// dx.doi.org/10.1016/j.cell.2015.10.067.

[69] N.J. Abbott, A.A.K. Patabendige, D.E.M. Dolman, S.R. Yusof, D.J. Begley, Structure and function of the blood-brain barrier, Neurobiol. Dis. 37 (2010) 13-25, http://dx.doi.org/10.1016/j.nbd.2009.07.030.

[70] M. Mackay, A.M. Ulug, B.T. Volpe, Neuropsychiatric systemic lupus erythematosus: mechanisms of injury, in: R.G. Lahita, G. Tsokos, J. Buyon, T. Koike (Eds.), Syst. Lupus Erythematosus, fifth ed., Elsevier, , London, 2011, pp. 491-511.

[71] L.B. Jaeger, S. Dohgu, R. Sultana, J.L. Lynch, J.B. Owen, M.A. Erickson, et al., Lipopolysaccharide alters the blood-brain barrier transport of amyloid beta protein: a mechanism for inflammation in the progression of Alzheimer's disease, Brain Behav. Immun. 23 (2009) 507-517, http://dx.doi.org/10.1016/ 
j.bbi.2009.01.017.

[72] H. Yokoo, S. Chiba, K. Tomita, M. Takashina, H. Sagara, S. Yagisita, et al., Neurodegenerative evidence in mice brains with cecal ligation and puncture-induced sepsis: preventive effect of the free radical scavenger edaravone, PLoS One 7 (2012), http://dx.doi.org/10.1371/journal.pone.0051539 e51539.

[73] H. Noh, J. Jeon, H. Seo, Systemic injection of LPS induces region-specific neuroinflammation and mitochondrial dysfunction in normal mouse brain Neurochem. Int. 69 (2014) 35-40, http://dx.doi.org/10.1016 j.neuint.2014.02.008.

[74] H.A. Silverman, M. Dancho, A. Regnier-Golanov, M. Nasim, M. Ochani, P.S. Olofsson, et al., Brain region-specific alterations in the gene expression of cytokines, immune cell markers and cholinergic system components during peripheral endotoxin-induced inflammation, Mol. Med. 20 (2014) 601-611, http://dx.doi.org/10.2119/molmed.2014.00147.

[75] S.T. Anderson, S. Commins, P.N. Moynagh, A.N. Coogan, Lipopolysaccharideinduced sepsis induces long-lasting affective changes in the mouse, Brain Behav. Immun. 43 (2015) 98-109, http://dx.doi.org/10.1016/ j.bbi.2014.07.007.

[76] H.Q. Fu, T. Yang, W. Xiao, L. Fan, Y. Wu, N. Terrando, et al., Prolonged neuroinflammation after lipopolysaccharide exposure in aged rats, PLoS One 9 (2014), http://dx.doi.org/10.1371/journal.pone.0106331 e106331.

[77] B.R. Lauwerys, F.A. Houssiau, Involvement of cytokines in the pathogenesis of systemic lupus erythematosus, Adv. Exp. Med. Biol. 520 (2003) 237-251.

[78] R. Dantzer, Cytokine, sickness behavior, and depression, Immunol. Allergy Clin. North Am. 29 (2009) 247-264, http://dx.doi.org/10.1016/ j.iac.2009.02.002.

[79] A. Rolls, R. Shechter, A. London, Y. Ziv, A. Ronen, R. Levy, et al., Toll-like receptors modulate adult hippocampal neurogenesis, Nat. Cell Biol. 9 (2007) 1081-1088, http://dx.doi.org/10.1038/ncb1629.

[80] L. Santarelli, M. Saxe, C. Gross, A. Surget, F. Battaglia, S. Dulawa, et al., Requirement of hippocampal neurogenesis for the behavioral effects of antidepressants, Science 301 (2003) 805-809, http://dx.doi.org/10.1126/ science. 1083328.

[81] R. Dantzer, J.C. O'Connor, G.G. Freund, R.W. Johnson, K.W. Kelley, From inflammation to sickness and depression: when the immune system subjugates the brain, Nat. Rev. Neurosci. 9 (2008) 46-56, http://dx.doi.org/ 10.1038/nrn2297.

[82] J.P. Godbout, B.M. Berg, C. Krzyszton, R.W. Johnson, Alpha-tocopherol attenuates NFkappaB activation and pro-inflammatory cytokine production in brain and improves recovery from lipopolysaccharide-induced sickness behavior, J. Neuroimmunol. 169 (2005) 97-105, http://dx.doi.org/10.1016/ j.jneuroim.2005.08.003.

[83] A. Nadjar, R.-M. Bluthé, M.J. May, R. Dantzer, P. Parnet, Inactivation of the cerebral NFkappaB pathway inhibits interleukin-1beta-induced sickness behavior and c-Fos expression in various brain nuclei, Neuropsychopharmacology 30 (2005) 1492-1499, http://dx.doi.org/10.1038/ sj.npp. 1300755.

[84] T. Yoshio, H. Okamoto, K. Kurasawa, Y. Dei, S. Hirohata, S. Minota, IL-6, IL-8, IP-10, MCP-1 and G-CSF are significantly increased in cerebrospinal fluid but not in sera of patients with central neuropsychiatric lupus erythematosus, Lupus (2016), http://dx.doi.org/10.1177/0961203316629556.

[85] K. Ichinose, K. Arima, M. Umeda, S. Fukui, A. Nishino, Y. Nakashima, et al., Predictors of clinical outcomes in patients with neuropsychiatric systemic lupus erythematosus, Cytokine 79 (2016) 31-37, http://dx.doi.org/10.1016 j.cyto.2015.12.010

[86] A.H. Miller, C. Raison, The role of inflammation in depression: from evolutionary imperative to modern treatment target, Nat. Rev. Immunol. 16 (2016) 22-34.

[87] S.J. Motivala, A. Sarfatti, L. Olmos, M.R. Irwin, Inflammatory markers and sleep disturbance in major depression, Psychosom. Med. 67 (2005) 187-194, http://dx.doi.org/10.1097/01.psy.0000149259.72488.09.

[88] Y. Katsumata, M. Harigai, Y. Kawaguchi, C. Fukasawa, M. Soejima, K. Takagi, et al., Diagnostic reliability of cerebral spinal fluid tests for acute confusional state (delirium) in patients with systemic lupus erythematosus: interleukin 6 (IL-6), IL-8, interferon-alpha, IgG index, and Q-albumin, J. Rheumatol. 34 (2007) 2010-2017.

[89] D.M. Santer, T. Yoshio, S. Minota, T. Möller, K.B. Elkon, Potent induction of IFN-alpha and chemokines by autoantibodies in the cerebrospinal fluid of patients with neuropsychiatric lupus, J. Immunol. 182 (2009) 1192-1201.

[90] L. Brydon, N.A. Harrison, C. Walker, A. Steptoe, H.D. Critchley, Peripheral inflammation is associated with altered substantia nigra activity and psychomotor slowing in humans, Biol. Psychiatry 63 (2008) 1022-1029, http:/ dx.doi.org/10.1016/j.biopsych.2007.12.007.

[91] A. Reichenberg, R. Yirmiya, A. Schuld, T. Kraus, M. Haack, A. Morag, et al. Cytokine-associated emotional and cognitive disturbances in humans, Arch. Gen. Psychiatry 58 (2001) 445-452.

[92] N. Terrando, A. Rei Fidalgo, M. Vizcaychipi, M. Cibelli, D. Ma, C. Monaco, et al., The impact of IL-1 modulation on the development of lipopolysaccharideinduced cognitive dysfunction, Crit. Care 14 (2010) R88, http://dx.doi.org/ 10.1186/cc9019.

[93] S.S. Ousman, P. Kubes, Immune surveillance in the central nervous system, Nat. Neurosci. 15 (2012) 1096-1101, http://dx.doi.org/10.1038/nn.3161.

[94] R.M. Ransohoff, B. Engelhardt, The anatomical and cellular basis of immune surveillance in the central nervous system, Nat. Rev. Immunol. 12 (2012)
623-635, http://dx.doi.org/10.1038/nri3265.

95] M. Schwartz, K. Baruch, The resolution of neuroinflammation in neurodegeneration: leukocyte recruitment via the choroid plexus, EMBO J. 33 (2014) 7-22, http://dx.doi.org/10.1002/embj.201386609.

[96] K.M. Khanna, A.J. Lepisto, V. Decman, R.L. Hendricks, Immune control of herpes simplex virus during latency, Curr. Opin. Immunol. 16 (2004) 463-469, http://dx.doi.org/10.1016/j.coi.2004.05.003.

[97] D.R. Green, T. Ferguson, L. Zitvogel, G. Kroemer, Immunogenic and tolerogenic cell death, Nat. Rev. Immunol. 9 (2009) 353-363, http://dx.doi.org/ 10.1038/nri2545.

[98] B.S. Franklin, L. Bossaller, D. De Nardo, J.M. Ratter, A. Stutz, G. Engels, et al., The adaptor ASC has extracellular and "prionoid" activities that propagate inflammation, Nat. Immunol. 15 (2014) 727-737, http://dx.doi.org/10.1038/ ni.2913.

[99] S.M. Man, T.-D. Kanneganti, Converging roles of caspases in inflammasome activation, cell death and innate immunity, Nat. Rev. Immunol. 16 (2016) 7-21, http://dx.doi.org/10.1038/nri.2015.7.

[100] M.A. Burguillos, T. Deierborg, E. Kavanagh, A. Persson, N. Hajji, A. GarciaQuintanilla, et al., Caspase signalling controls microglia activation and neurotoxicity, Nature 472 (2011) 319-324, http://dx.doi.org/10.1038/ nature09788.

[101] R. Sankowski, S. Mader, S.I. Valdés-Ferrer, Systemic inflammation and the brain: novel roles of genetic, molecular, and environmental cues as drivers of neurodegeneration, Front. Cell. Neurosci. 9 (2015) 28, http://dx.doi.org/ 10.3389/fncel.2015.00028.

[102] J. Dieker, V. Iglesias-Guimarais, M. Décossas, J. Stevenin, J. van der Vlag, V.J. Yuste, et al., Early apoptotic reorganization of spliceosomal proteins involves caspases, CAD and rearrangement of NuMA, Traffic Cph Den. 13 (2012) 257-272, http://dx.doi.org/10.1111/j.1600-0854.2011.01307.x.

[103] C. Kaur, V. Sivakumar, Z. Zou, E.-A. Ling, Microglia-derived proinflammatory cytokines tumor necrosis factor-alpha and interleukin-1beta induce Purkinje neuronal apoptosis via their receptors in hypoxic neonatal rat brain, Brain Struct. Funct. 219 (2014) 151-170, http://dx.doi.org/10.1007/s00429-0120491-5.

[104] B. Diamond, G. Honig, S. Mader, L. Brimberg, B.T. Volpe, Brain-reactive antibodies and disease, Annu. Rev. Immunol. 31 (2013) 345-385, http:// dx.doi.org/10.1146/annurev-immunol-020711-075041.

[105] M. Mackay, C. Tang, B. Volpe, C. Aranow, P. Mattis, R. Korff, et al., Brain metabolism and autoantibody titres predict functional impairment in systemic lupus erythematosus, Lupus Sci. Med. 2 (2015), http://dx.doi.org/ 10.1136/lupus-2014-000074.

[106] T.W. Faust, E.H. Chang, C. Kowal, R. Berlin, I.G. Gazaryan, E. Bertini, et al., Neurotoxic lupus autoantibodies alter brain function through two distinct mechanisms, Proc. Natl. Acad. Sci. 107 (2010) 18569-18574, http:// dx.doi.org/10.1073/pnas.1006980107.

[107] E. Coutinho, P. Harrison, A. Vincent, Do neuronal autoantibodies cause psychosis? a neuroimmunological perspective, Biol. Psychiatry 75 (2014) 269-275, http://dx.doi.org/10.1016/j.biopsych.2013.07.040.

[108] S.J. Crisp, D.M. Kullmann, A. Vincent, Autoimmune synaptopathies, Nat. Rev. Neurosci. 17 (2016) 103-117, http://dx.doi.org/10.1038/nrn.2015.27.

[109] R. Höftberger, Neuroimmunology: an expanding frontier in autoimmunity, Front. Immunol. 6 (2015) 206, http://dx.doi.org/10.3389/fimmu.2015.00206.

[110] J. Dalmau, M.R. Rosenfeld, Autoimmune encephalitis update, Neuro Oncol. 16 (2014) 771-778, http://dx.doi.org/10.1093/neuonc/nou030.

[111] R.C. Dale, S.R. Irani, F. Brilot, S. Pillai, R. Webster, D. Gill, et al., N-methyl-Daspartate receptor antibodies in pediatric dyskinetic encephalitis lethargica, Ann. Neurol. 66 (2009) 704-709, http://dx.doi.org/10.1002/ana.21807.

[112] J. Dalmau, E. Tüzün, H. Wu, J. Masjuan, J.E. Rossi, A. Voloschin, et al,, Paraneoplastic anti-N-methyl-D-aspartate receptor encephalitis associated with ovarian teratoma, Ann. Neurol. 61 (2007) 25-36, http://dx.doi.org/10.1002/ ana.21050.

[113] H.E. Peery, G.S. Day, S. Dunn, M.J. Fritzler, H. Prüss, C. De Souza, et al., AntiNMDA receptor encephalitis. The disorder, the diagnosis and the immunobiology, Autoimmun. Rev. 11 (2012) 863-872, http://dx.doi.org/10.1016/ j.autrev.2012.03.001.

[114] N. Gresa-Arribas, M.J. Titulaer, A. Torrents, E. Aguilar, L. McCracken, F. Leypoldt, et al., Antibody titres at diagnosis and during follow-up of antiNMDA receptor encephalitis: a retrospective study, Lancet Neurol. 13 (2014) 167-177, http://dx.doi.org/10.1016/S1474-4422(13)70282-5.

[115] E.G. Hughes, X. Peng, A.J. Gleichman, M. Lai, L. Zhou, R. Tsou, et al., Cellular and synaptic mechanisms of anti-NMDA receptor encephalitis, J. Neurosci. 30 (2010) 5866-5875, http://dx.doi.org/10.1523/JNEUROSCI.0167-10.2010.

[116] J.M. Pego-Reigosa, T. Cobo-Ibáñez, J. Calvo-Alén, E. Loza-Santamaría, A. Rahman, S. Muñoz-Fernández, et al., Efficacy and safety of nonbiologic immunosuppressants in the treatment of nonrenal systemic lupus erythematosus: a systematic review, Arthritis Care Res. 65 (2013) 1775-1785, http://dx.doi.org/10.1002/acr.22035.

[117] L. Dreyer, M. Faurschou, M. Mogensen, S. Jacobsen, High incidence of potentially virus-induced malignancies in systemic lupus erythematosus: a long-term followup study in a Danish cohort, Arthritis Rheum. 63 (2011) 3032-3037, http://dx.doi.org/10.1002/art.30483.

[118] A. Holck Draborg, S. Jacobsen, M. Westergaard, S. Mortensen, J.L. Larsen, G. Houen, et al., Reduced response to Epstein-Barr virus antigens by T-cells in systemic lupus erythematosus patients, Lupus Sci. Med. 1 (2014) e000015, http://dx.doi.org/10.1136/lupus-2014-000015. 
[119] E. Zard, L. Arnaud, A. Mathian, Z. Chakhtoura, M. Hie, P. Touraine, et al., Increased risk of high grade cervical squamous intraepithelial lesions in systemic lupus erythematosus: a meta-analysis of the literature, Autoimmun. Rev. 13 (2014) 730-735, http://dx.doi.org/10.1016/ j.autrev.2014.03.001.

[120] N. Agmon-Levin, Z. Paz, E. Israeli, Y. Shoenfeld, Vaccines and autoimmunity, Nat. Rev. Rheumatol. 5 (2009) 648-652, http://dx.doi.org/10.1038/ nrrheum.2009.196.

[121] G. Murdaca, A. Orsi, F. Spanò, F. Puppo, P. Durando, G. Icardi, et al., Influenza and pneumococcal vaccinations of patients with systemic lupus erythematosus: current views upon safety and immunogenicity, Autoimmun. Rev. 13 (2014) 75-84, http://dx.doi.org/10.1016/j.autrev.2013.07.007.

[122] P. Pellegrino, S. Radice, E. Clementi, Immunogenicity and safety of the human papillomavirus vaccine in patients with autoimmune diseases: a systematic review, Vaccine 33 (2015) 3444-3449, http://dx.doi.org/10.1016/ j.vaccine.2015.05.041.

[123] Y. Fei, X. Shi, F. Gan, X. Li, W. Zhang, M. Li, et al., Death causes and pathogens analysis of systemic lupus erythematosus during the past 26 years, Clin. Rheumatol. 33 (2014) 57-63, http://dx.doi.org/10.1007/s10067-013-2383-3.

[124] M.G. Tektonidou, Z. Wang, A. Dasgupta, M.M. Ward, Burden of serious infections in adults with systemic lupus erythematosus. A national populationbased Study, 1996-2011, Arthritis Care Res. (2015), http://dx.doi.org/ 10.1002/acr.22575.

[125] M. Yurkovich, K. Vostretsova, W. Chen, J.A. Aviña-Zubieta, Overall and causespecific mortality in patients with systemic lupus erythematosus: a metaanalysis of observational studies, Arthritis Care Res. 66 (2014) 608-616, http://dx.doi.org/10.1002/acr.22173.

[126] J. Widdifield, S. Bernatsky, Connective tissue diseases: the burden of serious infections in SLE, Nat. Rev. Rheumatol. 11 (2015) 326-327, http://dx.doi.org/ 10.1038/nrrheum.2015.55.

[127] J.H. Cho, M. Feldman, Heterogeneity of autoimmune diseases: pathophysiologic insights from genetics and implications for new therapies, Nat. Med. 21 (2015) 730-738, http://dx.doi.org/10.1038/nm.3897.

[128] F. Wang, S. Muller, Manipulating autophagic processes in autoimmune diseases: a special focus on modulating chaperone-mediated autophagy, an emerging therapeutic target, Front. Immunol. 6 (2015) 252, http:// dx.doi.org/10.3389/fimmu.2015.00252.

[129] N. Schall, S. Muller, Resetting the autoreactive immune system with a therapeutic peptide in lupus, Lupus 24 (2015) 412-418, http://dx.doi.org/ $10.1177 / 0961203314556138$.

[130] R. Zimmer, H.R. Scherbarth, O.L. Rillo, J.J. Gomez-Reino, S. Muller, Lupuzor/ P140 peptide in patients with systemic lupus erythematosus: a randomised, double-blind, placebo-controlled phase IIb clinical trial, Ann. Rheum. Dis. 72 (2013) 1830-1835, http://dx.doi.org/10.1136/annrheumdis-2012-202460.

[131] N. Page, F. Gros, N. Schall, M. Décossas, D. Bagnard, J.-P. Briand, et al., HSC70 blockade by the therapeutic peptide P140 affects autophagic processes and endogenous MHCII presentation in murine lupus, Ann. Rheum. Dis. 70 (2011) 837-843, http://dx.doi.org/10.1136/ard.2010.139832.

[132] C. Macri, F. Wang, I. Tasset, N. Schall, N. Page, J.-P. Briand, et al., Modulation of deregulated chaperone-mediated autophagy by a phosphopeptide, Autophagy $11 \quad$ (2015) 472-486, http://dx.doi.org/10.1080/ 15548627.2015.1017179.

[133] E. Wong, A.M. Cuervo, Autophagy gone awry in neurodegenerative diseases, Nat. Neurosci. 13 (2010) 805-811, http://dx.doi.org/10.1038/nn.2575.

[134] G. Morris, M. Maes, A neuro-immune model of Myalgic Encephalomyelitis/ Chronic fatigue syndrome, Metab. Brain Dis. 28 (2013) 523-540, http:// dx.doi.org/10.1007/s11011-012-9324-8.
[135] G. Morris, M. Maes, Oxidative and nitrosative stress and immuneinflammatory pathways in patients with myalgic encephalomyelitis (ME)/ Chronic fatigue syndrome (CFS), Curr. Neuropharmacol. 12 (2014) 168-185. http://dx.doi.org/10.2174/1570159X11666131120224653.

[136] G.J. Dover, The Barker hypothesis: how pediatricans will diagnose and prevent common adult-onset diseases, Trans. Am. Clin. Climatol. Assoc. 120 (2009) 199-207.

[137] S.D. Bilbo, J.M. Schwarz, Early-life programming of later-life brain and behavior: a critical role for the immune system, Front. Behav. Neurosci. 3 (2009) 14, http://dx.doi.org/10.3389/neuro.08.014.2009.

[138] E. Romero, C. Guaza, B. Castellano, J. Borrell, Ontogeny of sensorimotor gating and immune impairment induced by prenatal immune challenge in rats: implications for the etiopathology of schizophrenia, Mol. Psychiatry 15 (2010) 372-383, http://dx.doi.org/10.1038/mp.2008.44.

[139] A.-M. Samuelsson, E. Jennische, H.-A. Hansson, A. Holmäng, Prenatal exposure to interleukin-6 results in inflammatory neurodegeneration in hippocampus with NMDA/GABA(A) dysregulation and impaired spatial learning, Am. J. Physiol. Regul. Integr. Comp. Physiol. 290 (2006) R1345-R1356, http://dx.doi.org/10.1152/ajpregu.00268.2005.

[140] S.E.P. Smith, J. Li, K. Garbett, K. Mirnics, P.H. Patterson, Maternal immune activation alters fetal brain development through interleukin-6, J. Neurosci. 27 (2007) 10695-10702, http://dx.doi.org/10.1523/JNEUROSCI.217807.2007.

[141] C. Konradt, C.A. Hunter, Immune-mediated viral clearance from the CNS without collateral damage, J. Exp. Med. 212 (2015) 1141-1142, http:// dx.doi.org/10.1084/jem.2128insight3.

[142] A. Louveau, T.H. Harris, J. Kipnis, Revisiting the mechanisms of CNS immune privilege, Trends Immunol. 36 (2015) 569-577.

[143] A. Louveau, I. Smirnov, T.J. Keyes, J.D. Eccles, S.J. Rouhani, J.D. Peske, et al., Structural and functional features of central nervous system lymphatic vessels, Nature (2015), http://dx.doi.org/10.1038/nature14432.

[144] M.V. Russo, D.B. McGavern, Immune surveillance of the CNS following infection and injury, Trends Immunol. 36 (2015) 637-650.

[145] The American College of Rheumatology nomenclature and case definitions for neuropsychiatric lupus syndromes, Arthritis Rheum. 42 (1999) 599-608, http://dx.doi.org/10.1002/1529-0131(199904)42:4<599::AIDANR2>3.0.CO;2-F.

[146] H. Jeltsch-David, S. Muller, Neuropsychiatric systemic lupus erythematosus and cognitive dysfunction: the MRL-lpr mouse strain as a model, Autoimmun. Rev. 13 (2014) 963-973, http://dx.doi.org/10.1016/ j.autrev.2014.08.015.

[147] C.L. Vanderlugt, S.D. Miller, Epitope spreading in immune-mediated diseases: implications for immunotherapy, Nat. Rev. Immunol. 2 (2002) 85-95, http://dx.doi.org/10.1038/nri724.

[148] E. Lancaster, M.G.M. Huijbers, V. Bar, A. Boronat, A. Wong, E. MartinezHernandez, et al., Investigations of caspr2, an autoantigen of encephalitis and neuromyotonia, Ann. Neurol. 69 (2011) 303-311, http://dx.doi.org/ 10.1002 /ana.22297.

[149] E. Lancaster, E. Martinez-Hernandez, J. Dalmau, Encephalitis and antibodies to synaptic and neuronal cell surface proteins, Neurology 77 (2011) 179-189, http://dx.doi.org/10.1212/WNL.0b013e318224afde.

[150] M.R. Rosenfeld, J. Dalmau, Anti-NMDA-receptor encephalitis and other synaptic autoimmune disorders, Curr. Treat. Options Neurol. 13 (2011) 324-332, http://dx.doi.org/10.1007/s11940-011-0116-y.

[151] M.R. Rosenfeld, M.J. Titulaer, J. Dalmau, Paraneoplastic syndromes and autoimmune encephalitis: five new things, Neurol. Clin. Pract. 2 (2012) 215-223, http://dx.doi.org/10.1212/CPJ.0b013e31826af23e. 